Journal of Inorganic and General Chemistry

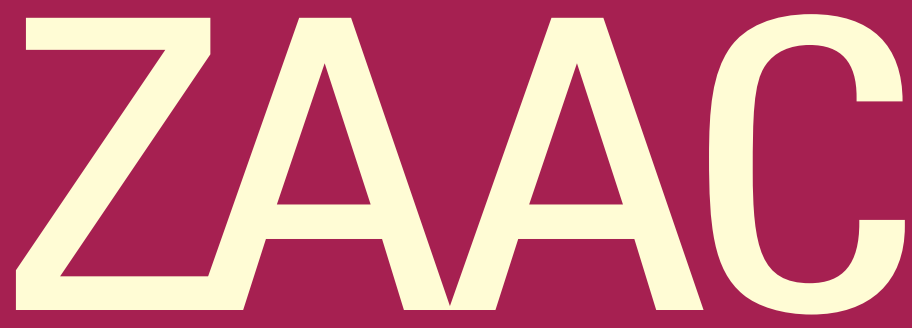

Zeitschrift für anorganische und allgemeine Chemie

\title{
2019
}

645/14 Porous Diamondoid Framework

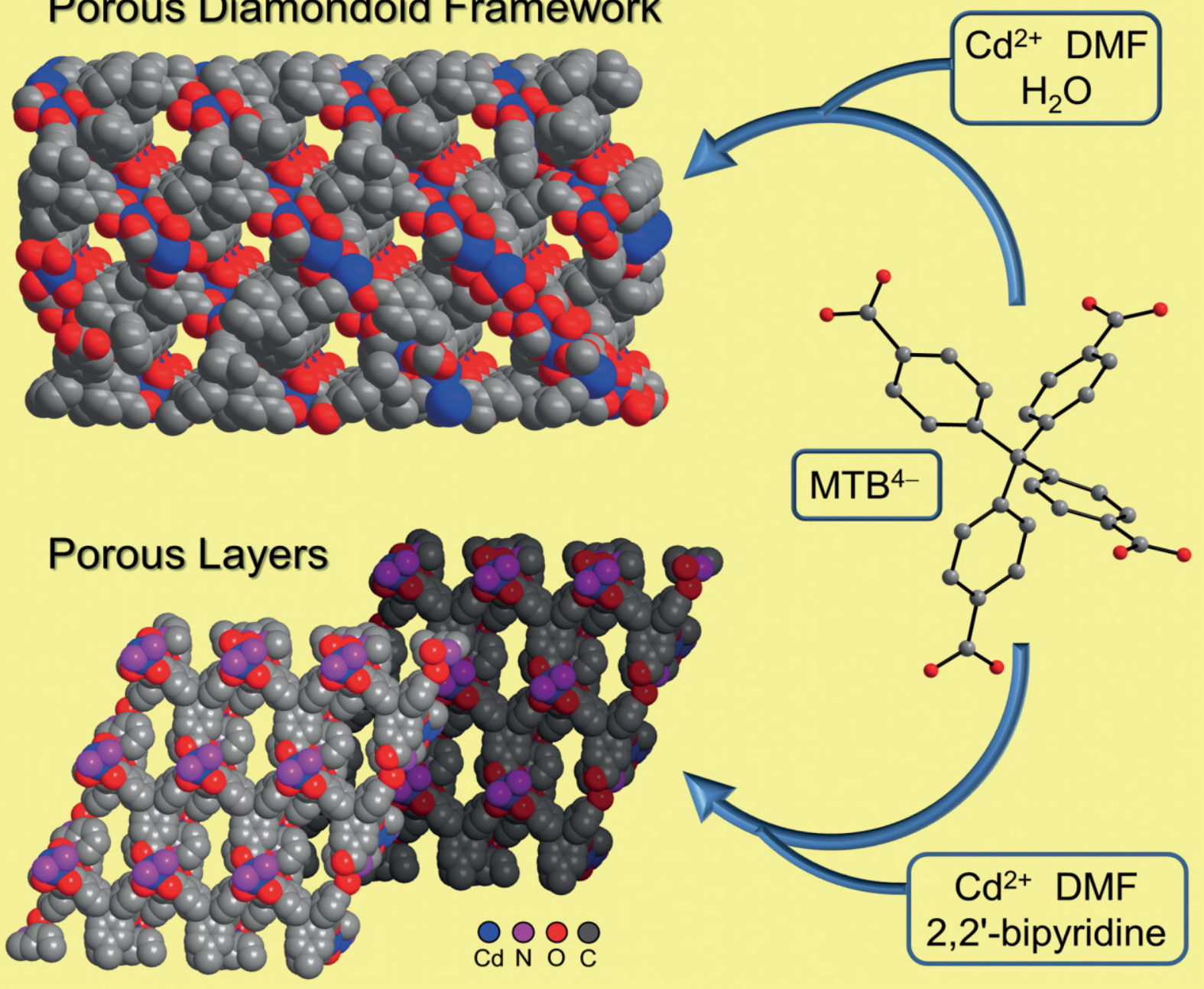

Front Cover: Syntheses and Crystal Structures of Two Cadmium Methanetetrabenzoates Featured by Open Framework and Infinite Layers

Sven Harms, Roberto Köferstein, Helmar Görls, and Christian Robl 


\title{
Z. Anorg. Allg. Chem. 645 (2019) 912-918. \\ DOI: 10.1002/zaac.201900089
}

https://doi.org/10.1002/zaac.201900089

\section{Syntheses and Crystal Structures of Two Cadmium Methanetetrabenzoates Featured by Open Framework and Infinite Layers}

\author{
Sven Harms ${ }^{a}$, Roberto Köferstein ${ }^{b}$, Helmar Görls ${ }^{a}$, and Christian Robl ${ }^{a}$ \\ a) Institute of Inorganic and Analytical Chemistry, Friedrich-Schiller-University Jena, Humboldtstrasse 8, 07743 Jena, Germany \\ b) Institute of Chemistry, Inorganic Chemistry, Martin Luther University Halle-Wittenberg, Kurt-Mothes-Strasse 2, 06120 Halle, Germany
}

\begin{abstract}
Colourless single crystals of $\mathrm{Cd}_{2}\left[\mu_{8}-\mathrm{MTB}\right] \cdot 3 \mathrm{H}_{2} \mathrm{O} \cdot \mathrm{DMF}$ (1) were prepared in $\mathrm{DMF} / \mathrm{H}_{2} \mathrm{O}$ solution. 1: Space group $\mathrm{C} 2 / \mathrm{c}$ (no. 15) with $a=1821.30(6), b=2175.08(6), c=$ 1269.87(4) pm, $\beta=129.684(1)^{\circ}$. The connection between the methane-p-benzoate tetraanions $\left(\mathrm{MTB}^{4-}\right)$ and the $\mathrm{Cd}^{2+}$ cations leads to a three-dimensional framework with channels extending along [ 10] and [110] with openings of $670 \mathrm{pm} \times 360 \mathrm{pm}$. The channel-like voids accommodate water molecules and $N, N$-dimethylformamide (DMF) molecules not bound to $\mathrm{Cd}^{2+}$. Colourless single crystals of $\left[\mathrm{Cd}_{4}\left(2,2^{\prime} \text {-bipy }\right)_{4}\left(\mu_{7}-\mathrm{MTB}\right)_{2}\right] \cdot 7 \mathrm{DMF}(2)$ were prepared in DMF in the presence of 2,2'-bipyridine. 2: Space group P (no. 2) with $a=1224.84(4), b=$ 1418.85(5), $c=2033.49(4) \mathrm{pm}, \alpha=85.831(2)^{\circ}, \beta=88.351(2)^{\circ}, \gamma=68.261(1)^{\circ}$. The coordination of $\mathrm{MTB}^{4-}$ to $\mathrm{Cd}^{2+}$ results in infinite layers parallel to (001). The layers, not connected by any hydrogen bonds, contain small openings of about $320 \mathrm{pm} \times 340 \mathrm{pm}$.
\end{abstract}

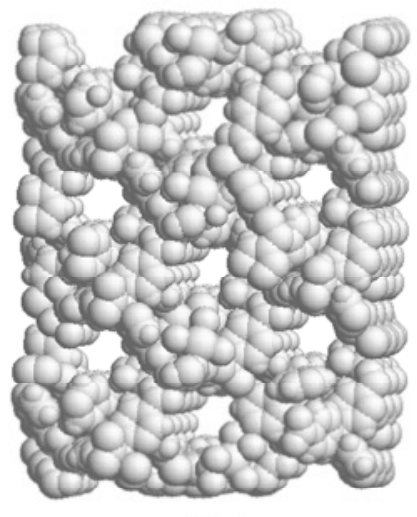

3D

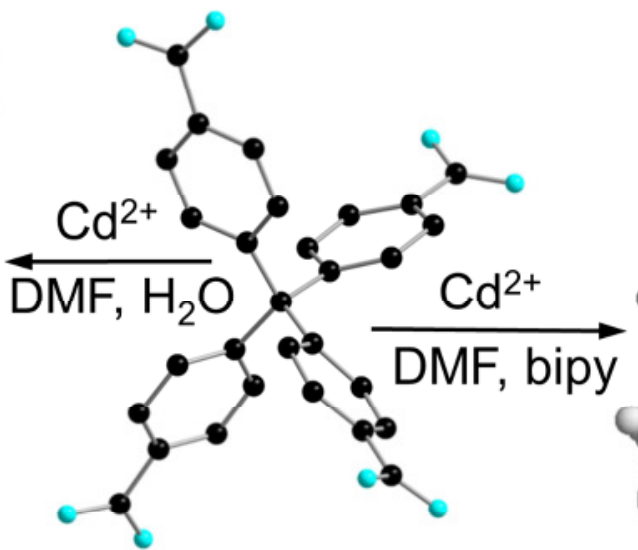

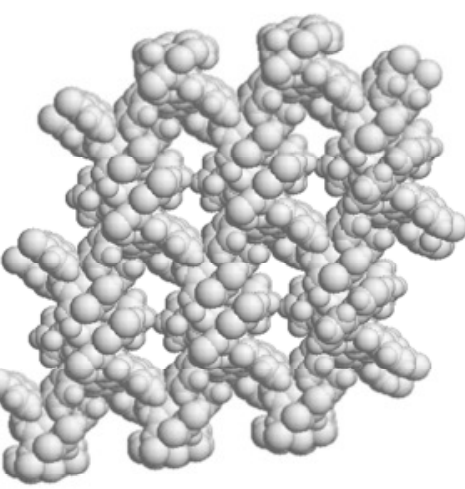

2D 


\title{
Syntheses and Crystal Structures of Two Cadmium Methanetetrabenzoates Featured by Open Framework and Infinite Layers
}

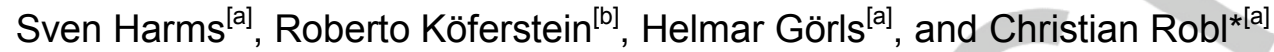

\begin{abstract}
Colourless single crystals of $\mathrm{Cd}_{2}\left[\mu_{8}-\mathrm{MTB}\right] \cdot 3 \mathrm{H}_{2} \mathrm{O} \cdot \mathrm{DMF}$ (1) were prepared in $\mathrm{DMF} / \mathrm{H}_{2} \mathrm{O}$ solution. 1: Space group $\mathrm{C} 2 / \mathrm{c}$ (no. 15) with $a=1821.30(6), b=2175.08(6), c=1269.87(4) \mathrm{pm}, \beta=$ $129.684(1)^{\circ}$. The connection between the methane-p-benzoate tetraanions $\left(\mathrm{MTB}^{4-}\right)$ and the $\mathrm{Cd}^{2+}$ cations leads to a threedimensional framework with channels extending along [ 10] and [110] with openings of $670 \mathrm{pm} \times 360 \mathrm{pm}$. The channel-like voids accommodate water molecules and $\mathrm{N}, \mathrm{N}$-dimethylformamide (DMF) molecules not bound to $\mathrm{Cd}^{2+}$. Colourless single crystals of $\left[\mathrm{Cd}_{4}\left(2,2^{\prime}-\right.\right.$ bipy $\left.)_{4}\left(\mu_{7}-\mathrm{MTB}\right)_{2}\right] \cdot 7 \mathrm{DMF}(2)$ were prepared in DMF in the presence of 2,2'-bipyridine. 2: Space group $\mathrm{P}$ (no. 2) with $a=1224.84(4), b=$ 1418.85(5), $c=2033.49(4) \mathrm{pm}, \alpha=85.831(2)^{\circ}, \beta=88.351(2)^{\circ}, \gamma=$ $68.261(1)^{\circ}$. The coordination of $\mathrm{MTB}^{4-}$ to $\mathrm{Cd}^{2+}$ results in infinite layers parallel to (001). The layers, not connected by any hydrogen bonds, contain small openings of about $320 \mathrm{pm} \times 340 \mathrm{pm}$.
\end{abstract}

\section{Introduction}

Porous coordination polymers, often called metal-organic frameworks (MOFs), have attracted much attention due to their potential application e.g. as catalyst ${ }^{[1]}$, ion exchanger ${ }^{[2]}$, and in gas storage and separation processes ${ }^{[3}$. Hereby, polycarboxylate ligands are able to coordinate metal ions in flexible modes, resulting in various interesting complexes with one-, two, and three-dimensional structure motives. ${ }^{[4-8]}$ Building blocks with tetrahedrally directed functional groups will very likely build up frameworks related to the structure of diamond. Such diamond-like frameworks, often called diamondoid, have been veryfied in the crystal structure of methanetetraacetic acid (3,3-bis(carboxymethyl)glutaric acid) and adamantane-1,3,5,7tetracarboxylic acid.[ 9,10 ] These compounds feature interpenetrating networks. If it is possible to avoid

\footnotetext{
* Prof. Dr. C. Robl

Fax: +49-3641-948152

E-mail: crr@uni-jena.de

[a] Institute of Inorganic and Analytical Chemistry

Friedrich-Schiller-University Jena

Humboldtstrasse 8, 07743 Jena, Germany

[b] Institute of Chemistry, Inorganic Chemistry

Martin Luther University Halle-Wittenberg

Kurt-Mothes-Strasse 2

06120 Halle, Germany
}

Supporting information for this article is available on the WWW under http://dx.doi.org/10.1002/zaac.201000xxx or from the author. interpenetrating structures, open frameworks will result. Common examples are the mineral melanophlogite and various porous silica modifications. A platinum coordination compound with adamantoid cages has been reported very recently. ${ }^{[1]}$ Further three-dimensional and porous coordination polymers have been prepared using tetrahedral building units, like the anions of methanetetra-p-benzoic acid and tetrakis(4-carboxyphenyl)silane. ${ }^{[12-15]} A$ few three-dimensional open frameworks have been reported for the connection between the methanetetra-p-benzoate anion $\left(\mathrm{MTB}^{4-}\right)$ and metal cations $\left(\mathrm{Ni}^{2+}\right.$, $\left.\mathrm{Co}^{2+}, \mathrm{Cu}^{2+}, \mathrm{Zn}^{2+}, \mathrm{Cd}^{2+}, \mathrm{Zr}^{4+}, \mathrm{Pb}^{2+}\right) \cdot{ }^{[12,13,16-24]}$ Several transition metal methane-p-benzoates show selective gas adsorption behaviour for $\mathrm{CO}_{2}, \mathrm{H}_{2}$, and $\mathrm{O}_{2} \cdot{ }^{[12,17-19,25]}$ Additionally, $\left[\mathrm{Ni}_{2} \text { (cyclam) }\right)_{2}$ (MTB)] $8 \mathrm{H}_{2} \mathrm{O} \cdot 4 \mathrm{DMF}$ (DMF = dimethylformamide, cyclam = 1,4,8,11-tetraazacyclotetradecane) can be used to produce palladium nanoparticles, whereas $\left[\mathrm{Ni}_{4}\left(\mu_{6}-\mathrm{MTB}\right)_{2}\left(\mu_{2}-\right.\right.$ $\left.\left.\mathrm{H}_{2} \mathrm{O}\right)_{4}\left(\mathrm{H}_{2} \mathrm{O}\right)_{4}\right] \cdot 10 D M F \cdot 11 \mathrm{H}_{2} \mathrm{O}$ and $\left[\mathrm{Pb}_{4}\left(\mu_{8}-\mathrm{MTB}\right)_{2}\left(\mathrm{H}_{2} \mathrm{O}\right)_{4}\right]$ -5DMF. $\mathrm{H}_{2} \mathrm{O}$ act as catalysts in Knoevenagel condensation reactions. ${ }^{[17,18,26]}$

Herein, we report on the crystal structures of two cadmium(II) methanetetra-p-benzoates with a three- dimensional open framework ( $\left.\mathrm{Cd}_{2}\left[\mu_{8}-\mathrm{MTB}\right] \cdot 3 \mathrm{H}_{2} \mathrm{O} \cdot \mathrm{DMF}\right)$ and a two-dimensionally polymeric structure $\left(\left[\mathrm{Cd}_{4}\left(2,2^{\prime} \text {-bipy }\right)_{4}\left(\mu_{7}-\mathrm{MTB}\right)_{2}\right] \cdot 7 \mathrm{DMF}\right)$, respectively.

\section{Results and Discussion}

\section{$\mathrm{Cd}_{2}\left[\mu_{8}-\mathrm{MTB}\right] \cdot 3 \mathrm{H}_{2} \mathrm{O} \cdot \mathrm{DMF}(1)$}

In $\mathrm{Cd}_{2}\left[\mu_{8}-\mathrm{MTB}\right] \cdot 3 \mathrm{H}_{2} \mathrm{O} \cdot \mathrm{DMF}(1)$ there are two crystallographically independent $\mathrm{Cd}^{2+}$ cations. $\mathrm{Cd}(1)$ occupies a crystallographic inversion center (Wyckoff position 4c), whereas $\mathrm{Cd}(2)$ lies on a twofold crystallographic axis of space-group C2/c (Wyckoff position $4 e) . \mathrm{Cd}(1)$ is six-fold coordinated in a slightly distorted octahedral manner by four carboxylate oxygen atoms $[2 x \mathrm{O}(2)$, $2 x \mathrm{O}(4)$ ], from four crystallographically equivalent methanetetra$\mathrm{p}$-benzoate tetraanions $\left(\mathrm{MTB}^{4-}\right.$ ) and twice by the water molecule $\mathrm{O}(1 \mathrm{w})$ (Figure 1a). The $\mathrm{Cd}-\mathrm{O}$ distances range from 221.2(3) to 231.3(3) pm (Table 1). The bond angles within the octahedron differ marginally from the ideal values, except the angles between the oxygen atoms $\mathrm{O}(2)$ and $\mathrm{O}(4)$. Thus, the octahedron can be described by $D_{2 d}$ symmetry in good approximation. $\mathrm{Cd}(2)$ is surrounded by six carboxylate oxygen atoms stemming from four equivalent $\mathrm{MTB}^{4-}$ anions with bond lengths between 221.3(3) and 241.1(3) pm. The coordination polyhedron strongly 
deviates from an ideal octahedron as well as from an ideal trigonal prism (Figure 1b, Table 1). Thus the $\mathrm{Cd}(2)$ polyhedron can be best described as a distorted intermediate between an octahedral and a trigonal prismatic coordination. Employing the method of Brese and O'Keeffe ${ }^{[27]}$ the bond valence sum for $\mathrm{Cd}(1)$ and $\mathrm{Cd}(2)$ is calculated to 2.24 and 1.97 , respectively. Neighbouring $\mathrm{Cd}(1)$ and $\mathrm{Cd}(2)$ polyhedra are linked by a common corner $[\mathrm{O}(4)]$ leading to sinusoidal infinite polyhedra chains along [101] (Figure 1c). The shortest $\mathrm{Cd}(1) \cdots \mathrm{Cd}(2)$ contact is $387.53(2) \mathrm{pm}$.
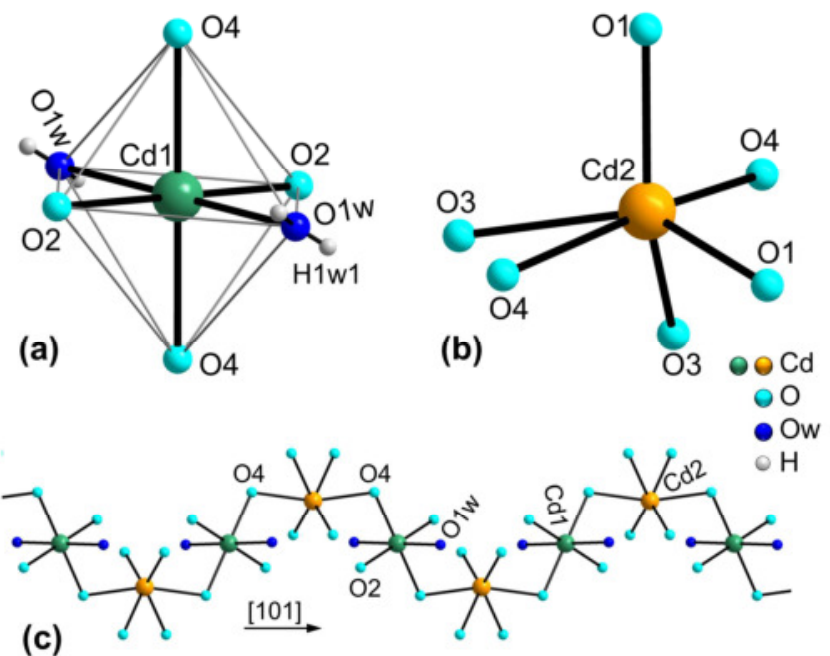

(c)

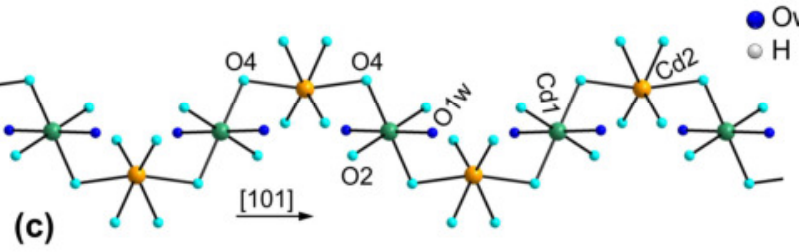

Figure 1. $(a, b)$ The coordination environment of $\mathrm{Cd}(1)$ and $\mathrm{Cd}(2)$ in $\mathrm{Cd}_{2}\left[\mu_{8}\right.$ MTB] $3 \mathrm{H}_{2} \mathrm{O} \cdot \mathrm{DMF}$ (1). (c) The connection between the $\mathrm{Cd}(1)$ and $\mathrm{Cd}(2)$ polyhedra leads to infinite chains (hydrogen atoms are omitted for clarity).

Table 1. The coordination of $\mathrm{Cd}^{2+}$ in $\mathrm{Cd}_{2}\left[\mu_{8}-\mathrm{MTB}\right] \cdot 3 \mathrm{H}_{2} \mathrm{O} \cdot \mathrm{DMF}$ (1)

\begin{tabular}{lccccc}
\hline \multicolumn{1}{l}{ Distances (pm) } \\
\hline $\mathrm{Cd}(1)-\mathrm{O}(2)$ & $228.7(3)$ & $2 \mathrm{x}$ & $\mathrm{Cd}(2)-\mathrm{O}(1)$ & $221.3(3)$ & $2 \mathrm{x}$ \\
$\mathrm{Cd}(1)-\mathrm{O}(4)$ & $231.3(3)$ & $2 \mathrm{x}$ & $\mathrm{Cd}(2)-\mathrm{O}(3)$ & $235.4(3)$ & $2 \mathrm{x}$ \\
$\mathrm{Cd}(1)-\mathrm{O}(1 \mathrm{w})$ & $221.2(3)$ & $2 \mathrm{x}$ & $\mathrm{Cd}(2)-\mathrm{O}(4)$ & $241.1(3)$ & $2 \mathrm{x}$ \\
\hline $\mathrm{Bond}$ angles $\left(^{\circ}\right)$ & & & & \\
\hline $\mathrm{O}(1 \mathrm{w})^{\# 1}-\mathrm{Cd}(1)-\mathrm{O}(1 \mathrm{w})$ & 180.0 & $\mathrm{O}(1)^{\# 4}-\mathrm{Cd}(2)-\mathrm{O}(3)$ & $98.89(11)$ \\
$\mathrm{O}(1 \mathrm{w})-\mathrm{Cd}(1)-\mathrm{O}(2)$ & $92.10(12)$ & $\mathrm{O}(1)^{\# 4}-\mathrm{Cd}(2)-\mathrm{O}(1)^{\# 5}$ & $107.59(15)$ \\
$\mathrm{O}(1 \mathrm{w})-\mathrm{Cd}(1)-\mathrm{O}(2)^{\# 1}$ & $87.90(12)$ & $\mathrm{O}(1)^{\# 5}-\mathrm{Cd}(2)-\mathrm{O}(4)$ & $86.88(10)$ \\
$\mathrm{O}(1 \mathrm{w})^{\# 1}-\mathrm{Cd}(1)-\mathrm{O}(4)^{\# 2}$ & $88.15(13)$ & $\mathrm{O}(1)^{\# 5}-\mathrm{Cd}(2)-\mathrm{O}(3)$ & $137.52(11)$ \\
$\mathrm{O}(1 \mathrm{w})^{\# 1}-\mathrm{Cd}(1)-\mathrm{O}(4)^{\# 3}$ & $91.85(13)$ & $\mathrm{O}(1)^{\# 4}-\mathrm{Cd}(2)-\mathrm{O}(4)$ & $102.14(10)$ \\
$\mathrm{O}(2)-\mathrm{Cd}(1)-\mathrm{O}(4)^{\# 2}$ & $99.12(10)$ & $\mathrm{O}(3)^{\# 6}-\mathrm{Cd}(2)-\mathrm{O}(3)$ & $81.94(16)$ \\
$\mathrm{O}(2)-\mathrm{Cd}(1)-\mathrm{O}(2)^{\# 1}$ & 180.0 & $\mathrm{O}(3)-\mathrm{Cd}(2)-\mathrm{O}(4)$ & $54.85(10)$ \\
$\mathrm{O}(2)-\mathrm{Cd}(1)-\mathrm{O}(4)^{\# 3}$ & $80.88(10)$ & $\mathrm{O}(3)-\mathrm{Cd}(2)-\mathrm{O}(4)^{\# 6}$ & $112.07(10)$
\end{tabular}

$\mathrm{O}(4)^{\# 2}-\mathrm{Cd}(1)-\mathrm{O}(4)^{\# 3} \quad 180.00(16) \quad \mathrm{O}(4)-\mathrm{Cd}(2)-\mathrm{O}(4)^{\# 6} \quad 164.78(13)$

Symmetry codes: $\# 1:-x+0.5 ;-y+0.5 ;-z, \# 2:-x ;-y ;-z, \# 3: x+0.5 ; y+0.5 ; z, \# 4:-x+0.5 ; y-0.5 ;-z-$ $0.5, \# 5: x-0.5 ; y-0.5 ; z, \# 6:-x-1 ; y ;-z-0.5$

Chun et al. ${ }^{[20]}$ reported on a tetragonal three-dimensionally connected cadmium methanetetra-p-benzoate complex $\left(\left[\mathrm{Cd}_{4}(\mathrm{MTB})_{2}(\mathrm{DMF})_{4}\right] \cdot 4 \mathrm{DMF} \cdot 4 \mathrm{H}_{2} \mathrm{O}\right)$ in which the seven-fold coordinated $\mathrm{Cd}^{2+}$ cations form tetranuclear clusters and all carboxylate groups act as chelate ligands.

The tetraanion of the methanetetra-p-benzoic acid $\left(\mathrm{MTB}^{4-}\right)$ is situated on a twofold axis. The $\mathrm{C}-\mathrm{O}$ bond length in the carboxylate groups are in the range between 124.7(5) and $127.6(5) \mathrm{pm}$. The carboxylate groups with $\mathrm{C}(8)$ are nearly coplanar to the $\mathrm{C}_{6}$ rings (torsion angle $2.3(3)^{\circ}$ ) and the carboxylate groups with $\mathrm{C}(15)$ are slightly twisted by $9.7(4)^{\circ}$. Moreover, the phenyl rings are twisted against each other by $63.3(1)^{\circ}$ to $74.2(2)^{\circ}$. Each $\mathrm{MTB}^{4-}$ anion connects eight cadmium cations and adopts a $\mu_{8}$ coordination mode (Figure 2a). All carboxylate oxygen atoms are involved in the coordination to $\mathrm{Cd}^{2+}$. The carboxylate groups with $\mathrm{C}(15)$ are bonded to $\mathrm{Cd}(1)$ in a monodentate and to $\mathrm{Cd}(2)$ in a bidentate manner. The coordination leads to a $\mu_{2}-\eta^{2}: \eta^{1}$ connection mode. Whereas the carboxylate groups with $\mathrm{C}(8)$ show only a monodentate coordination to $\mathrm{Cd}^{2+}$ with a $\mu_{2}-\eta^{1}: \eta^{1}$ mode.

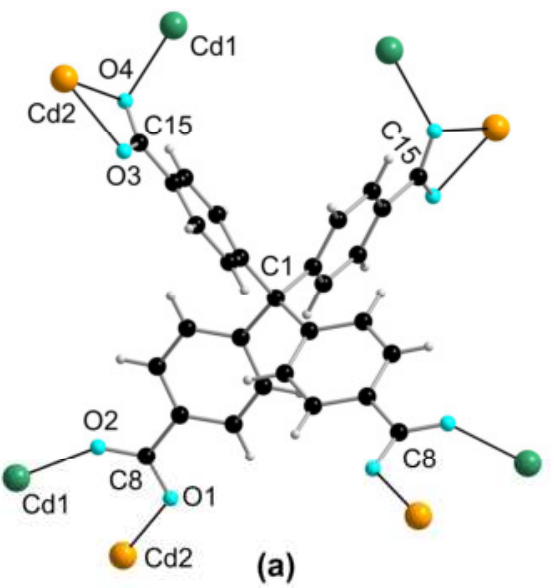

(a)

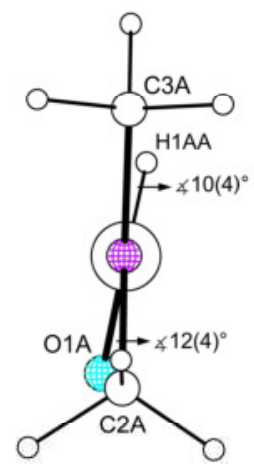

(b)
Figure 2. (a) The connection between the tetraanion of the methanetetra-pbenzoic acid $\left(\mathrm{MTB}^{4-}\right.$ ) and the $\mathrm{Cd}^{2+}$ cations in (1). (b) Newman projection of the $\mathrm{N}, \mathrm{N}$-dimethylformamide (DMF) molecule along $\mathrm{N}(1 \mathrm{~A})-\mathrm{C}(1 \mathrm{~A})$. 
Table 2. Selected bond lengths and angles of the $\mathrm{MTB}^{4-}$ anion in $\mathrm{Cd}_{2}\left[\mu_{8}-\right.$ MTB] $3 \mathrm{H}_{2} \mathrm{O} \cdot \mathrm{DMF}$ (1)

\begin{tabular}{lccc}
\hline Distances $(\mathrm{pm})$ & & \\
\hline $\mathrm{C}(8)-\mathrm{O}(1)$ & $127.6(5)$ & $\mathrm{C}(15)-\mathrm{O}(3)$ & $125.4(5)$ \\
$\mathrm{C}(8)-\mathrm{O}(2)$ & $124.7(5)$ & $\mathrm{C}(15)-\mathrm{O}(4)$ & $127.0(5)$ \\
$\mathrm{C}(5)-\mathrm{C}(8)$ & $151.0(5)$ & $\mathrm{C}(12)-\mathrm{C}(15)$ & $149.5(5)$ \\
$\mathrm{C}(1)-\mathrm{C}(2)$ & $154.5(4)$ & $\mathrm{C}(1)-\mathrm{C}(9)$ & $155.3(4)$ \\
\hline $\mathrm{Bond}$ angles $\left(^{\circ}\right)$ & & & \\
\hline $\mathrm{O}(1)-\mathrm{C}(8)-\mathrm{O}(2)$ & $124.9(3)$ & $\mathrm{O}(3)-\mathrm{C}(15)-\mathrm{O}(4)$ & $120.9(4)$ \\
$\mathrm{O}(2)-\mathrm{C}(8)-\mathrm{C}(5)$ & $119.1(3)$ & $\mathrm{O}(3)-\mathrm{C}(15)-\mathrm{C}(12)$ & $120.0(4)$ \\
$\mathrm{C}(9)-\mathrm{C}(1)-\mathrm{C}(9)^{\# 7}$ & $108.6(4)$ & $\mathrm{C}(2)-\mathrm{C}(1)-\mathrm{C}(2)^{\# 7}$ & $107.5(4)$ \\
$\mathrm{C}(2)-\mathrm{C}(1)-\mathrm{C}(9)$ & $110.02(18)$ & $\mathrm{C}(2)-\mathrm{C}(1)-\mathrm{C}(9)^{\# 7}$ & $110.34(18)$ \\
\hline
\end{tabular}

Symmetry code: \#7: -x;y;-z+0.5

The cadmium centered polyhedra chains are linked by $\mathrm{MTB}^{4-}$ anions to an open three-dimensional framework (Figures 3, 4). Each $\mathrm{MTB}^{4-}$ anion connects three Cd-polyhedra chains (Figure S1, Supporting Information). Channel-like voids extend along [ 10] and [110]. The openings of these channels are approximately $670 \mathrm{pm} \times 360 \mathrm{pm}$ with van der Waals radii ${ }^{[28]}$ of the framework atoms taken into account. The channels accommodate in a disordered manner water molecules $[\mathrm{O}(2 \mathrm{w})$, $\mathrm{O}(3 \mathrm{w})]$ and $\mathrm{N}, \mathrm{N}$-dimethylformamide (DMF) molecules not bound to $\mathrm{Cd}^{2+}$. Figure $2 \mathrm{~b}$ shows the Newman projection of the DMF molecule along the $\mathrm{N}(1 \mathrm{~A})-\mathrm{C}(1 \mathrm{~A})$ bond. The torsion angles between $C(2 \mathrm{~A}) / \mathrm{O}(1 \mathrm{~A})$ and $\mathrm{C}(3 \mathrm{~A}) / \mathrm{O}(1 \mathrm{~A})$ of $12(4)^{\circ}$ and $170(2)^{\circ}$ are comparable with values found in gaseous DMF. ${ }^{[29]}$ The DMF molecules are only connected to the framework by weak $\mathrm{C}-\mathrm{H} \cdots \mathrm{O}$ contacts to the phenyl rings (Table 3). Furthermore, the coordinated water molecule $\mathrm{O}(1 \mathrm{w})$ acts as donator in medium and strong hydrogen bonds to the uncoordinated water molecules $[\mathrm{O}(2 \mathrm{w}), \mathrm{O}(3 \mathrm{w})]$ and to the carboxylate oxygen atom $\mathrm{O}(1)$. The water molecule $\mathrm{O}(2 \mathrm{w})$ builds up a weak hydrogen bond to the DMF oxygen atom $\mathrm{O}(1 \mathrm{~A})$.

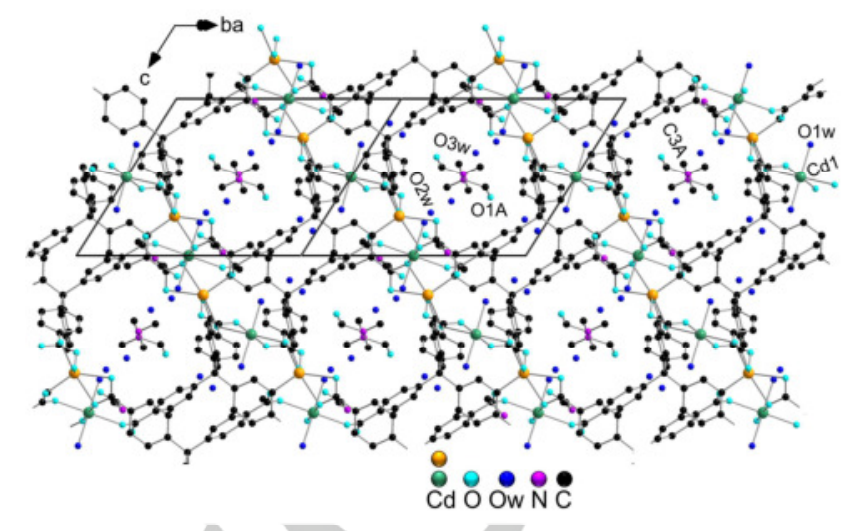

Figure 3. Crystal structure of $\mathrm{Cd}_{2}\left[\mu_{8}-\mathrm{MTB}\right] \cdot 3 \mathrm{H}_{2} \mathrm{O} \cdot \mathrm{DMF}$ (1) viewed from [ 10]. Hydrogen atoms are omitted for clarity.

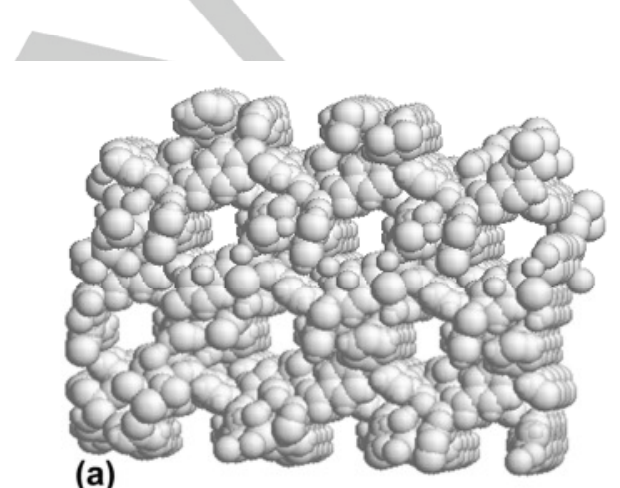

(a)

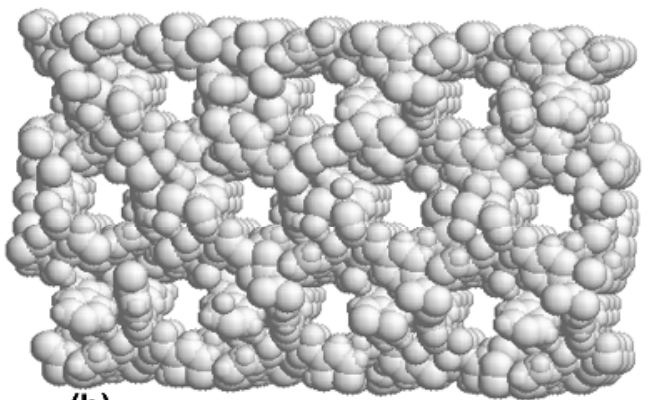

(b)

Figure 4. Space-filling model of the framework of 1. (a) view along [ 10], (b) view along [110]. DMF molecules and uncoordinated water molecules are omitted.

Table 3. Hydrogen bonds in 1

\begin{tabular}{|c|c|c|}
\hline & $\begin{array}{l}\text { O... D Distance } \\
(\mathrm{pm})\end{array}$ & $\mathrm{O}-\mathrm{H} \cdots \mathrm{O}$ Angle $\left({ }^{\circ}\right)$ \\
\hline $\mathrm{O}(1 \mathrm{w})-\mathrm{H}(1 \mathrm{w} 1) \cdots \mathrm{O}(2 \mathrm{w})$ & $262.3(10)$ & $143(1)$ \\
\hline $\mathrm{O}(1 \mathrm{w})-\mathrm{H}(1 \mathrm{w} 1) \cdots \mathrm{O}(3 \mathrm{w})$ & $258.2(10)$ & $159(1)$ \\
\hline $\mathrm{O}(1 \mathrm{w})-\mathrm{H}(2 \mathrm{w} 1) \cdots \mathrm{O}(1)_{\mathrm{MTB}}$ & $269.8(5)$ & $169(1)$ \\
\hline
\end{tabular}




\begin{tabular}{|c|c|c|}
\hline$O(2 w)-H(2 w B) \ldots O(1 A)_{D M F}$ & $264.4(10)$ & 136(1) \\
\hline & $\begin{array}{l}\text { C...O Distance } \\
(\mathrm{pm})\end{array}$ & $\mathrm{C}-\mathrm{H} \cdots \mathrm{O}$ Angle $\left({ }^{\circ}\right)$ \\
\hline $\mathrm{C}(11)_{M T B}-\mathrm{H}(11 \mathrm{~A}) \ldots \mathrm{O}(1 \mathrm{~A})_{\mathrm{DMF}}$ & $374.3(10)$ & $147(1)$ \\
\hline
\end{tabular}

\section{$\left[C d_{4}\left(2,2^{\prime}-\right.\right.$ bipy $\left._{4}\left(\mu_{7}-M T B\right)_{2}\right] \cdot 7 \mathrm{DMF}(2)$}

In 2, the cadmium cations occupy general positions of space group $\mathrm{P} . \mathrm{Cd}(1)$ is surrounded by two nitrogen atoms $[\mathrm{N}(1)$, $\mathrm{N}(2)$ ] from the 2,2'-bipyridine (bipy) molecule (I) and six carboxylate oxygen atoms from three different but crystallographically equivalent $\mathrm{MTB}^{4-}$ anions. The $\mathrm{Cd}(1)-\mathrm{N}$ distances are 231.9(6) and 234.9(6) pm, respectively (Table 4). The $\mathrm{Cd}(1)-\mathrm{O}$ bond lengths to $\mathrm{O}(2), \mathrm{O}(3), \mathrm{O}(4), \mathrm{O}(5)$, and $\mathrm{O}(6)$ are in the range between 224.4(5) and 254.9(5) pm, whereas the bond to $\mathrm{O}(1)$ is $284.3(7) \mathrm{pm}$. Although this $\mathrm{Cd}-\mathrm{O}$ bond is weak, it is significantly shorter than the sum of the van der Waals radii. A similar situation was reported with several $\mathrm{Cd}$ complexes. ${ }^{[28,30-37]}$ The resulting coordination $(7+1)$ can be approximately described as a distorted two-capped octahedron. As seen in Fig. $5 a$, the equatorial plane is spanned by $\mathrm{N}(1), \mathrm{O}(3)$ $\mathrm{O}(4)$, and $\mathrm{O}(5)$ deviating slightly from planarity with an average and maximum deviation of 4.4(3) pm and 5.2(7) pm, respectively. The axial positions are occupied by the nitrogen atom $\mathrm{N}(2)$ and the carboxylate oxygen atom $\mathrm{O}(2)$. Alternatively, the coordination polyhedron might also be considered as a monocapped pentagonal bipyramid with $O(1)$ as the capping atom. However, the pentagonal equatorial plane through $\mathrm{N}(1)$, $\mathrm{O}(3), \mathrm{O}(4), \mathrm{O}(5)$ and $\mathrm{O}(6)$ deviates considerably from planarity (average 20.6(4) pm) with a maximum deviation of 35.3(6) pm for $\mathrm{O}(6)$. The coordination sphere of $\mathrm{Cd}(2)$ is built up by two nitrogen atoms [N(3), $\mathrm{N}(4)]$ from the 2,2'-bipyridine molecule (II) and five carboxylate oxygen atoms $[\mathrm{O}(1), \mathrm{O}(3), \mathrm{O}(6), \mathrm{O}(7), \mathrm{O}(8)]$ stemming from four crystallographically equivalent $\mathrm{MTB}^{4-}$ anions. The coordination environment $(\mathrm{cn}=7$ ) forms a strongly distorted monocapped octahedron with $\mathrm{O}(7)$ as the capping atom (Fig. $5 b)$. The bond lengths are 231.5(7) and 234.8(8) pm for $\mathrm{Cd}(2)-\mathrm{N}$ and 225.1(5)-266.9(6) pm for $\mathrm{Cd}(2)-\mathrm{O}$. The bond angles within the $\mathrm{Cd}(1)$ and $\mathrm{Cd}(2)$ polyhedra differ significantly from those in an ideal octahedron (Table 4). According to Brese and O'Keeffe ${ }^{[27]}$ the bond valence sum for $\mathrm{Cd}(1)$ and $\mathrm{Cd}(2)$ was calculated to 2.14 and 2.15 , respectively.

As shown in Fig. $5 \mathrm{c}$, neighbouring $\mathrm{Cd}(1)$ and $\mathrm{Cd}(2)$ polyhedra share a common face $[O(1), O(3), O(6)]$ leading to dimeric polyhedra units. The $\mathrm{Cd}(1) \cdots \mathrm{Cd}(2)$ distance is $347.32(7) \mathrm{pm}$.
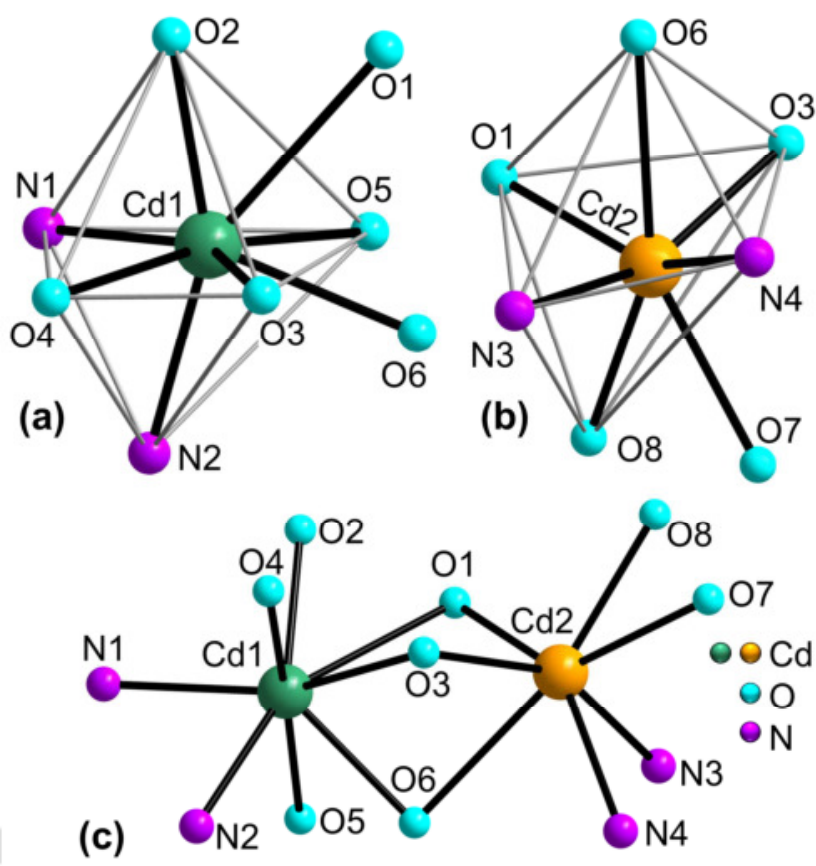

Figure 5. $(a, b)$ The coordination spheres of $\mathrm{Cd}^{2+}$ in $\left[\mathrm{Cd}_{4}\left(2,2^{\prime}-\text { bipy }\right)_{4}\left(\mu_{7^{-}}\right.\right.$ MTB $)_{2}$ ] 7DMF (2). (c) Connection between the $\mathrm{Cd}(1)$ and $\mathrm{Cd}(1)$ polyhedra.

Table 4. The coordination of $\mathrm{Cd}^{2+}$ in $\left.\mathrm{Cd}_{4}\left(2,2^{\prime} \text {-bipy }\right)_{4}\left(\mu_{7}-\mathrm{MTB}\right)_{2}\right] \cdot 7 \mathrm{DMF}(2)$

\begin{tabular}{|c|c|c|c|}
\hline \multicolumn{4}{|l|}{ Distances (pm) } \\
\hline $\mathrm{Cd}(1)-\mathrm{O}(1)$ & $284.3(7)$ & $\mathrm{Cd}(2)-\mathrm{O}(1)$ & $227.0(6)$ \\
\hline $\mathrm{Cd}(1)-\mathrm{O}(2)$ & $224.4(5)$ & $\mathrm{Cd}(2)-\mathrm{O}(3)$ & $225.1(5)$ \\
\hline $\mathrm{Cd}(1)-\mathrm{O}(3)$ & $238.9(5)$ & $\mathrm{Cd}(2)-\mathrm{O}(6)$ & $266.9(6)$ \\
\hline $\mathrm{Cd}(1)-\mathrm{O}(4)$ & $254.9(5)$ & $\mathrm{Cd}(2)-\mathrm{O}(7)$ & $246.3(6)$ \\
\hline $\mathrm{Cd}(1)-\mathrm{O}(5)$ & $254.7(5)$ & $\mathrm{Cd}(2)-\mathrm{O}(8)$ & $234.3(6)$ \\
\hline $\mathrm{Cd}(1)-\mathrm{O}(6)$ & $233.2(5)$ & $\mathrm{Cd}(2)-\mathrm{N}(3)$ & $231.5(7)$ \\
\hline $\mathrm{Cd}(1)-\mathrm{N}(1)$ & $231.9(6)$ & $\mathrm{Cd}(2)-\mathrm{N}(4)$ & $234.8(8)$ \\
\hline $\mathrm{Cd}(1)-\mathrm{N}(2)$ & $234.9(6)$ & & \\
\hline \multicolumn{4}{|l|}{ Bond angles $\left({ }^{\circ}\right)$} \\
\hline $\mathrm{O}(2)-\mathrm{Cd}(1)-\mathrm{N}(2)$ & $154.5(2)$ & $N(3)-C d(2)-N(4)$ & $70.8(3)$ \\
\hline$O(4)^{\# 2}-C d(1)-O(5)^{\# 1}$ & $170.81(18)$ & $\mathrm{O}(3)^{\# 2}-\mathrm{Cd}(2)-\mathrm{O}(7)^{\# 3}$ & $100.76(19)$ \\
\hline $\mathrm{N}(1)-\mathrm{Cd}(1)-\mathrm{O}(3)^{\# 2}$ & $146.3(2)$ & $\mathrm{O}(8)^{\# 3}-\mathrm{Cd}(2)-\mathrm{O}(7)^{\# 3}$ & $53.7(2)$ \\
\hline $\mathrm{O}(6)^{\# 1}-\mathrm{Cd}(1)-\mathrm{N}(2)$ & $83.15(18)$ & $\mathrm{O}(1)-\mathrm{Cd}(2)-\mathrm{N}(4)$ & $144.1(2)$ \\
\hline $\mathrm{O}(3)^{\# 2}-\mathrm{Cd}(1)-\mathrm{O}(5)^{\# 1}$ & $125.37(18)$ & $\mathrm{O}(3)^{\# 2}-\mathrm{Cd}(2)-\mathrm{N}(3)$ & $153.0(2)$ \\
\hline $\mathrm{N}(2)-\mathrm{Cd}(1)-\mathrm{O}(1)$ & $155.1(2)$ & $\mathrm{O}(6)^{\# 1}-\mathrm{Cd}(2)-\mathrm{O}(7)^{\# 3}$ & $149.5(2)$ \\
\hline
\end{tabular}

Symmetry codes: \#1: $x+2 ; y-1 ; z, \# 2: x-1 ; y ; z, \# 3:-x ;-y+1 ;-z+1$ 
The methanetetra-p-benzoate anion $\left(\mathrm{MTB}^{4-}\right)$ lies on a general crystallographic position. The phenyl rings within the $\mathrm{MTB}^{4-}$ anion are twisted against each other by $58.4(2)^{\circ}$ to $87.4(2)^{\circ}$. As seen in Figure 6 each tetraanion bridges seven cadmium cations. All carboxylate groups are bound to $\mathrm{Cd}(2)$ in a monodentate manner, except the $\mathrm{COO}^{-}$group with $\mathrm{C}(29)$, which coordinates in a bidentate mode only to $\mathrm{Cd}(2)$. The $\mathrm{Cd}(1)$ cations are exclusively bidentately coordinated by the carboxylate groups. Thus, the carboxylate group with $C(29)$ coordinates in a $\mu_{1}-\eta^{2}$ mode, whereas the remaining carboxylate groups show a $\mu_{2^{-}}$ $\eta^{2}: \eta^{1}$ connection. The $\mathrm{C}-\mathrm{O}$ bonds are between 121.4(12) and 128.7(9) pm (Table 5). The carboxylate groups with $C(8)$ and $\mathrm{C}(15)$ are slightly tilted to the $\mathrm{C}_{6}$ rings (torsion angles $7.0(5)^{\circ}$, $\left.3.9(4)^{\circ}\right)$, whereas the carboxylate groups with $C(22)$ and $C(29)$ are twisted by $23.9(3)^{\circ}$ and $15.5(5)^{\circ}$.

The two crystallographically independent 2,2'-bipyridine molecules (I, II) are planar with small torsion angles between the $\mathrm{C}_{5} \mathrm{~N}$-rings of $1.9(3)^{\circ}$ and $3.3(3)^{\circ}$, respectively

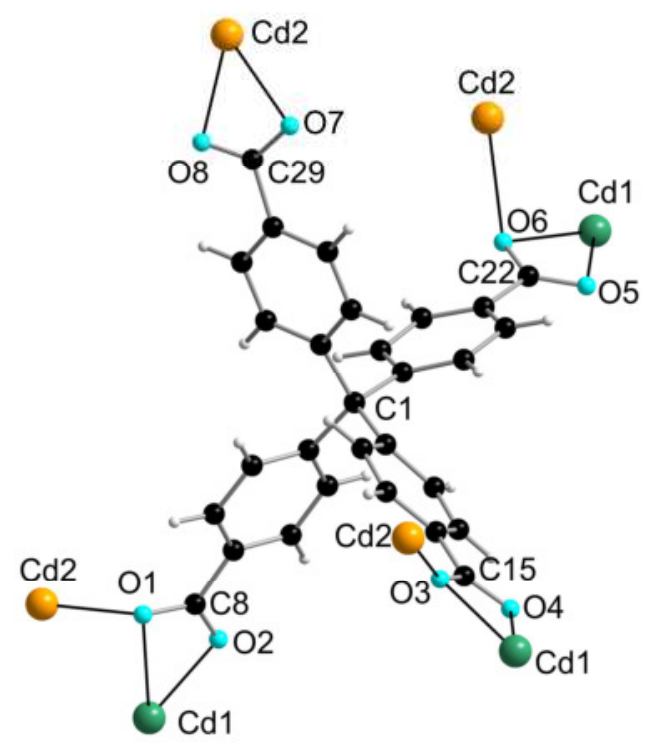

\begin{tabular}{|c|c|c|c|}
\hline $\mathrm{C}(15)-\mathrm{O}(4)$ & 124.3(9) & $C(29)-O(8)$ & $121.4(12)$ \\
\hline$C(5)-C(8)$ & $148.9(10)$ & $C(12)-C(15)$ & $149.0(10)$ \\
\hline$C(19)-C(22)$ & $151.7(10)$ & $C(26)-C(29)$ & $152.4(10)$ \\
\hline$C(1)-C(2)$ & $156.0(9)$ & $C(1)-C(16)$ & $155.2(9)$ \\
\hline$C(1)-C(9)$ & $152.7(9)$ & $C(1)-C(23)$ & $154.2(9)$ \\
\hline \multicolumn{4}{|l|}{ 2,2'-bipyridine I } \\
\hline$N(1)-C(30)$ & $133.5(11)$ & $N(2)-C(39)$ & $131.6(11)$ \\
\hline $\mathrm{N}(1)-\mathrm{C}(34)$ & $135.4(10)$ & $N(2)-C(35)$ & $134.4(9)$ \\
\hline \multicolumn{4}{|l|}{$C(33)-C(34)$} \\
\hline \multicolumn{4}{|l|}{ 2,2'-bipyridine II } \\
\hline$N(3)-C(40)$ & $132.2(12)$ & $\mathrm{N}(4)-\mathrm{C}(49)$ & $132.4(13)$ \\
\hline$N(3)-C(44)$ & 134.1(11) & $N(4)-C(45)$ & $135.0(11)$ \\
\hline$C(44)-C(45)$ & $149.9(13)$ & & \\
\hline \multicolumn{4}{|l|}{ Bond angles $\left({ }^{\circ}\right)$} \\
\hline \multicolumn{4}{|l|}{ MTB $^{4-}$} \\
\hline $\mathrm{O}(1)-\mathrm{C}(8)-\mathrm{O}(2)$ & 123.3(7) & $\mathrm{O}(5)-\mathrm{C}(22)-\mathrm{O}(6)$ & $123.4(7)$ \\
\hline $\mathrm{O}(3)-\mathrm{C}(15)-\mathrm{O}(4)$ & $120.9(7)$ & $\mathrm{O}(7)-\mathrm{C}(29)-\mathrm{O}(8)$ & $123.5(8)$ \\
\hline $\mathrm{O}(1)-\mathrm{C}(8)-\mathrm{C}(5)$ & 119.1(7) & $\mathrm{O}(3)-\mathrm{C}(15)-\mathrm{C}(12)$ & $118.5(6)$ \\
\hline $\mathrm{O}(5)-\mathrm{C}(22)-\mathrm{C}(19)$ & 119.8(7) & $O(7)-C(29)-C(26)$ & $118.2(8)$ \\
\hline$C(9)-C(1)-C(23)$ & $113.5(5)$ & $C(9)-C(1)-C(2)$ & $101.8(5)$ \\
\hline$C(23)-C(1)-C(2)$ & $113.1(6)$ & $C(9)-C(1)-C(16)$ & $113.1(6)$ \\
\hline$C(23)-C(1)-C(16)$ & $102.7(5)$ & $C(2)-C(1)-C(16)$ & $113.1(5)$ \\
\hline \multicolumn{4}{|l|}{ 2,2'-bipyridine I/II } \\
\hline$N(1)-C(34)-C(35)$ & $116.1(7)$ & $N(2)-C(35)-C(34)$ & $116.5(6)$ \\
\hline$N(3)-C(44)-C(45)$ & $116.9(7)$ & $\mathrm{N}(4)-C(45)-C(44)$ & $116.1(8)$ \\
\hline
\end{tabular}

Figure 6. The connection between the $[\mathrm{MTB}]^{4-}$ tetraanion and the cadmium cations in 2.

\begin{tabular}{|c|c|c|c|}
\hline \multicolumn{4}{|c|}{ Distances (pm) } \\
\hline \multicolumn{4}{|l|}{ MTB $^{4-}$} \\
\hline $\mathrm{C}(8)-\mathrm{O}(1)$ & $124.9(10)$ & $\mathrm{C}(22)-\mathrm{O}(5)$ & $124.9(10)$ \\
\hline $\mathrm{C}(8)-\mathrm{O}(2)$ & $128.3(10)$ & $\mathrm{C}(22)-\mathrm{O}(6)$ & $127.5(9)$ \\
\hline$C(15)-O(3)$ & $128.7(9)$ & $C(29)-O(7)$ & $125.5(11)$ \\
\hline
\end{tabular}




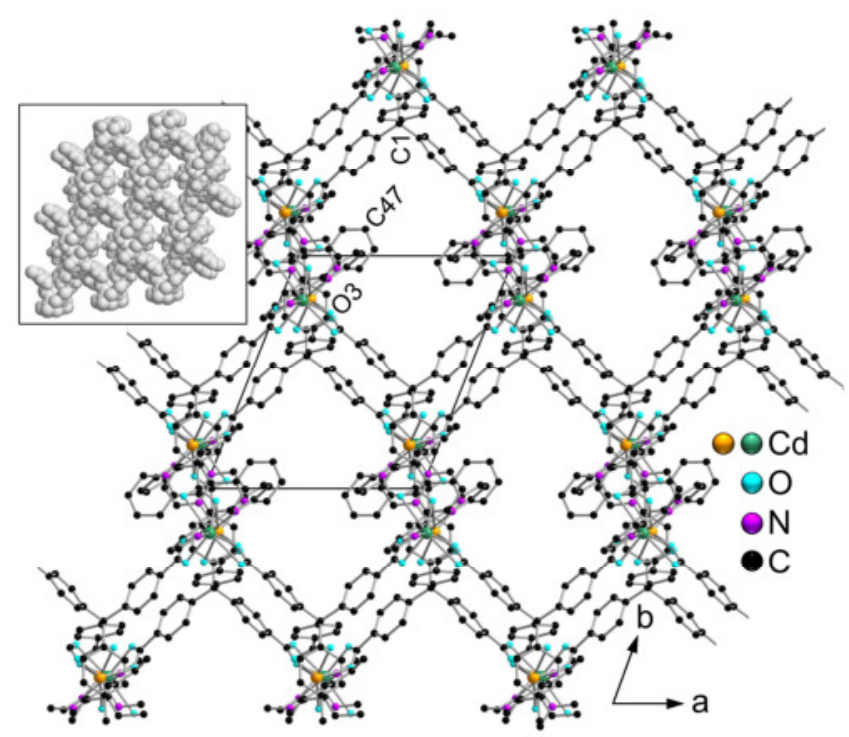

Figure 7. Crystal structure of $\left[\mathrm{Cd}_{4}\left(2,2^{\prime} \text {-bipy }\right)_{4}\left(\mu_{7}-\mathrm{MTB}\right)_{2}\right] \cdot 7 \mathrm{DMF}(2)$ viewed on (001). Hydrogen atoms and uncoordinated DMF molecules are omitted for clarity. The inset shows a space-filling model including hydrogen atoms.

In 2, the coordination of the $\mathrm{MTB}^{4-}$ tetraanions to the $\mathrm{Cd}(2)$ cations leads to infinite layers extending in the (001) plane (Figure 7 and 8) with honeycomb-like pattern. The connection between $\mathrm{Cd}(1)$ and $\mathrm{MTB}^{4-}$ leads to a stabilization of the structure by compensating the resulting negative charge of the layers. Each $\mathrm{MTB}^{4-}$ anion is linked to four dimeric $\mathrm{Cd}(1) / \mathrm{Cd}(2)$ polyhedra units. (Figure S2, Supporting Information) The 2,2'bipyridine molecules bound to $\mathrm{Cd}^{2+}$ are not essential for the twodimensionally infinite connection, but they complete the $\mathrm{Cd}$ coordination sphere. This obviously prevents from formation of a three-dimensional framework. The 2,2'-bipyridine molecule I extends into the openings of the layer acting as void filling group (Figure 7). The cavities along [001] (see inset in Figure 7) have dimensions of about $320 \mathrm{pm} \times 340 \mathrm{pm}$ (inclusive van der Waals radii $\left.{ }^{[28]}\right)$. The layers are stacked in a ...AA... sequence along the [001] direction. Neighbouring layers are not connected by any interlayer hydrogen bonds. On the other hand, the layers are confined by the 2,2'-bipyridine molecules (I) coordinated to $\mathrm{Cd}(1)$ pointing towards the interlayer space. As seen in Figure 9, the 2,2'-bipyridine molecules (I) are parallel to the 2,2'-bipyridine molecules (I) of the neighbouring layer along [ 10]. The distance between these 2,2'-bipyridine molecules is $348 \mathrm{pm}$ indicating a very close $\pi-\pi$ interaction between the bipyridine rings, which additionally stabilizes the crystal structure ${ }^{[38,39]}$ Within each layer, neighbouring 2,2'-bipyridine molecules (II) bound to $\mathrm{Cd}(2)$ are parallel to each other with a distance of $345 \mathrm{pm}$. There are five crystallographically independent DMF molecules (I-V) not bound to $\mathrm{Cd}^{2+}$, which are situated within the layers as well as intercalated between adjacent layers (Figure 8, S3, Supporting Information). The partly disordered DMF molecules form weak and medium $\mathrm{C}-\mathrm{H} \cdots \mathrm{O}$ hydrogen bonds to the phenyl rings of
$\mathrm{MTB}^{4-}$ and to the $\mathrm{C}_{5} \mathrm{~N}$-rings of the 2,2'-bipyridine molecules (Table 6). Some $\mathrm{C}-\mathrm{N}-\mathrm{C}-\mathrm{O}$ torsion angles of the DMF molecules $\left(0(3)^{\circ}-12(4)^{\circ}\right)$, differ considerably from the values found in gaseous DMF (Figure S4, Supporting Information). ${ }^{[2]}$ The small torsion angles of $4(2)^{\circ}$ in DMF II and $0(3)^{\circ}$ in DMF III are probably caused by the formation of strong $\mathrm{C}-\mathrm{H} \cdots \mathrm{O}$ hydrogen bonds with short $\mathrm{C} \cdots \mathrm{O}$ contacts.

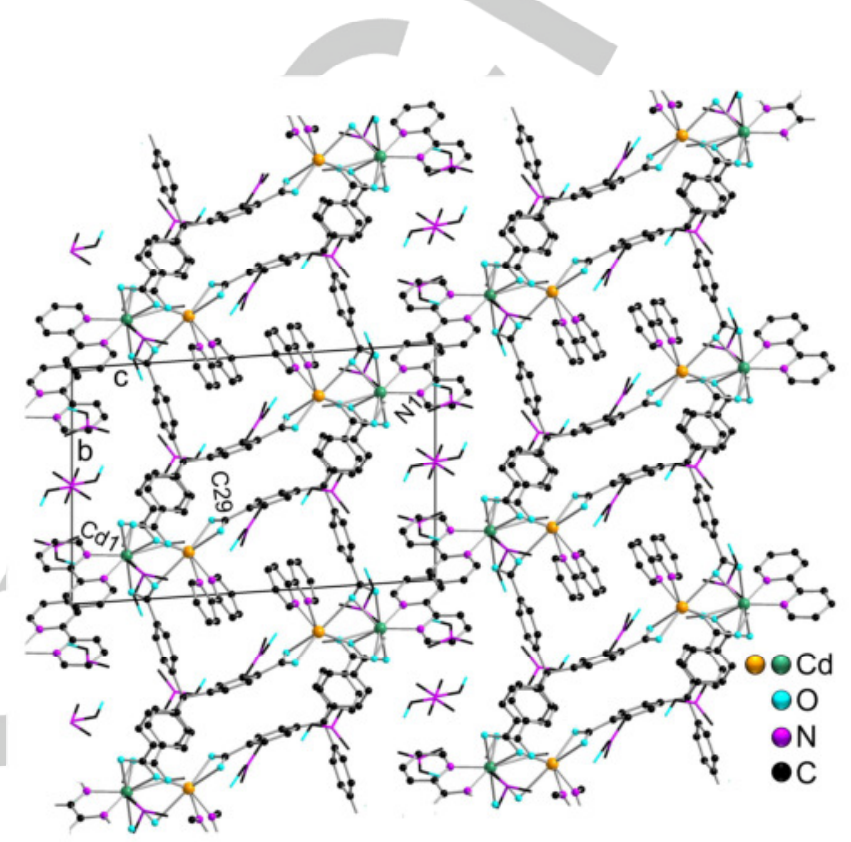

Figure 8. View along [100] in 2. DMF molecules are drawn as sticks Hydrogen atoms are omitted for clarity. 


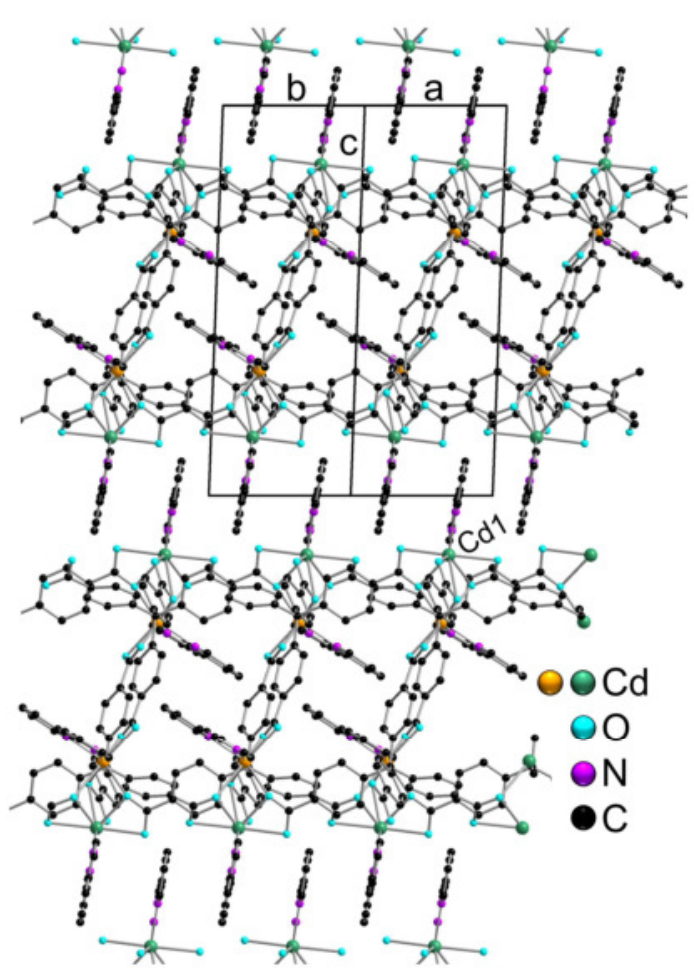

Figure 9. Crystal structure of 2 viewed from [110]. Hydrogen atoms and uncoordinated DMF molecules are omitted for clarity.

Table 6. Hydrogen bonds in 2

\begin{tabular}{|c|c|c|}
\hline & C...O Distance $(\mathrm{pm})$ & $\mathrm{C}-\mathrm{H} \cdots \mathrm{O}$ Angle $\left({ }^{\circ}\right)$ \\
\hline $\mathrm{C}(24)_{\mathrm{MTB}}-\mathrm{H}(24 \mathrm{~A}) \cdots \mathrm{O}(1 \mathrm{DA})_{\mathrm{DMF}-\mathrm{I}}$ & $338.6(16)$ & $147(1)$ \\
\hline $\mathrm{C}(21)_{\mathrm{MTB}}-\mathrm{H}(21 \mathrm{~A}) \cdots \mathrm{O}(1 \mathrm{DA})_{\mathrm{DMF}-\mathrm{I}}$ & $356.6(15)$ & $168(1)$ \\
\hline $\mathrm{C}(4)_{\mathrm{MTB}}-\mathrm{H}(4 \mathrm{~A}) \cdots \mathrm{O}(1 \mathrm{DB})_{\mathrm{DMF}-\|}$ & $351.4(12)$ & $157(1)$ \\
\hline $\mathrm{C}(6)_{\mathrm{MTB}}-\mathrm{H}(6 \mathrm{~A}) \cdots \mathrm{O}(1 \mathrm{DE})_{\mathrm{DMF}-\mathrm{V}}$ & $355(2)$ & 132(1) \\
\hline $\mathrm{C}(40)_{\text {MTB }}-\mathrm{H}(40 \mathrm{~A}) \cdots \mathrm{O}(1 \mathrm{DE})_{\text {DMF-V }}$ & $320(3)$ & 123(1) \\
\hline $\mathrm{C}(47)_{\text {bipy }}-\mathrm{H}(47 \mathrm{~A}) \cdots \mathrm{O}(1 \mathrm{DA})_{\text {DMF-I }}$ & $327.6(17)$ & $124(1)$ \\
\hline $\mathrm{C}(31)_{\text {bipy }}-\mathrm{H}(31 \mathrm{~A}) \cdots \mathrm{O}(1 \mathrm{DB})_{\mathrm{DMF}-I I}$ & $326.4(19)$ & $170(1)$ \\
\hline $\mathrm{C}(37)_{\text {bipy }}-\mathrm{H}(37 \mathrm{~A}) \cdots \mathrm{O}(1 \mathrm{DC})_{\text {DMF-III }}$ & $318(3)$ & 142(1) \\
\hline $\mathrm{C}(38)_{\text {bipy }}-\mathrm{H}(38 \mathrm{~A}) \cdots \mathrm{O}(1 \mathrm{DD})_{\mathrm{DMF}-\mathrm{IV}}$ & $377(3)$ & $154(1)$ \\
\hline $\mathrm{C}(48)_{\text {bipy }}-\mathrm{H}(48 \mathrm{~A}) \cdots \mathrm{O}(1 \mathrm{DD})_{\text {DMF-IV }}$ & $388(3)$ & $134(1)$ \\
\hline
\end{tabular}

\section{Conclusions}

We reported on the synthesis and structural properties of $\mathrm{Cd}_{2}\left[\mu_{8-}\right.$ MTB] $3 \mathrm{H}_{2} \mathrm{O} \cdot \mathrm{DMF}(1)$ and $\left[\mathrm{Cd}_{4}\left(2,2^{\prime} \text {-bipy }\right)_{4}\left(\mu_{7}-\mathrm{MTB}\right)_{2}\right] \cdot 7 \mathrm{DMF}(2)$. In
1 the connection between the $\mathrm{Cd}^{2+}$ cations and the $\mathrm{MTB}^{4-}$ tetraanions leads to an open three-dimensional framework with channels along [ 10] and [110]. The channels accommodate uncoordinated DMF and water molecules. Compound 2 was synthesized with 2,2'-bipyridine as an additional ligand. The $\mathrm{Cd}^{2+}$ cations are linked by $\mathrm{MTB}^{4-}$ anions to form infinite layers parallel to (001). The layers contain small openings. The 2,2'-bipyridine molecules act as $\mathrm{N}$-donor ligands completing the coordination environment of $\mathrm{Cd}^{2+}$. $\pi-\pi$ interactions between 2,2'-bipyridine rings of neighbouring layers obviously contribute to stabilize the structure. The results confirm that ligands with tetrahedrally directed functional groups favour the formation of diamondoid frameworks as expected and encourage further use of these buildings blocks.

\section{Experimental Section}

\section{Synthesis of Tetrakis(4-bromophenyl)methane ${ }^{[40]}$}

$54 \mathrm{mmol}$ tetraphenylmethane, synthesized as described elsewhere ${ }^{[41]}$, were slowly dropped in $60 \mathrm{ml}$ bromine in a round-bottomed flask under ice-cooling and stirred for $45 \mathrm{~min}$. Afterwards, $150 \mathrm{ml}$ ethanol was added (cooling with ice). The precipitate formed was collected by filtering and dried. The solid was dissolved in $500 \mathrm{ml} \mathrm{CHCl}_{3}$ and washed with aqueous $\mathrm{Na}_{2} \mathrm{SO}_{3}$ solution. The organic phase was distilled and the white product formed was recrystallized in a dioxane/ acetonitrile mixture. Yield: 63 \%. Elemental analysis: (molecular weight 636.01): C 46.46 (calcd. 47.21); H 2.30 (2.54); Br 51.24 (50.25). ${ }^{1} \mathrm{H}-\mathrm{NMR}$ (DMSO-d 6 ): $\delta$ $(\mathrm{ppm})=6.99,7.37 ;{ }^{13} \mathrm{C}-\mathrm{NMR}\left(\mathrm{DMSO}-\mathrm{d}_{6}\right): \delta(\mathrm{ppm})=63.6,120.8,131.1$, $132.4,144.4$

\section{Synthesis of Methanetetra-p-benzoic acid $\left(\mathrm{H}_{4} \mathrm{MTB}\right)^{[42]}$}

The reaction was carried out under argon atmosphere. $7.9 \mathrm{mmol}$ tetrakis(4-bromophenyl)methane was dissolved in $500 \mathrm{ml}$ dried THF. Buthyllithium was slowly dropped into the THF solution at $-70{ }^{\circ} \mathrm{C}$. The solution was stirred for $10 \mathrm{~min}$. Afterwards, $\mathrm{CO}_{2}$ was introduced for $2 \mathrm{~h}$ into the solution under stirring and the reaction mixture was meanwhile slowly heated to RT. After adding of half concentrated $\mathrm{HCl}$ the THF was distilled. The white residue was dissolved in aqueous $\mathrm{NaOH}$ and filtered through diatomaceous earth. The filtrate was acidified with $\mathrm{HCl}$. The formed precipitate of methanetetra-p-benzoic acid [tetrakis(4carboxyphenyl)methane] was collected and dried. Yield: $71 \%$. Elemental analysis: (molecular weight 496.46): C 68.78 (calcd. 70.16); H 4.51 (4.06). ${ }^{1} \mathrm{H}-\mathrm{NMR}\left(\right.$ DMSO-d 6 ): $\delta(\mathrm{ppm})=7.29,7.85 ;{ }^{13} \mathrm{C}-\mathrm{NMR}\left(\right.$ DMSO-d $\left._{6}\right): \delta(\mathrm{ppm})$ $=65.2,128.9,129.3,130.5,149.8,166.9$.

$\mathrm{Cd}_{2}\left[\boldsymbol{\mu}_{8}-\mathrm{MTB}\right] \cdot 3 \mathrm{H}_{2}$ O.DMF (1) ${ }^{[42]}: 0.2 \mathrm{mmol} \mathrm{H}_{4} \mathrm{MTB}$ and $0.4 \mathrm{mmol}$ $\mathrm{Cd}\left(\mathrm{NO}_{3}\right)_{2} \cdot 4 \mathrm{H}_{2} \mathrm{O}$ were dissolved in $5 \mathrm{ml}$ DMF ( $N, N$-dimethylformamide) and $2 \mathrm{ml}$ deionized water. The mixture was kept at about $50{ }^{\circ} \mathrm{C}$ in a drying oven. After several days, colourless crystals of 1 appeared.

[Cd $\left.{ }_{4}\left(2,2^{\prime} \text {-bipy }\right)_{4}\left(\mu_{7}-M T B\right)_{2}\right] \cdot 7 D M F(2)^{[42]}: 0.2 \mathrm{mmol} \mathrm{H}_{4} \mathrm{MTB}, 0.8 \mathrm{mmol}$ $2,2^{\prime}$-bipyridine, and $0.4 \mathrm{mmol} \mathrm{Cd}\left(\mathrm{NO}_{3}\right)_{2} \cdot 4 \mathrm{H}_{2} \mathrm{O}$ were dissolved in $7 \mathrm{ml}$ DMF. The mixture was kept at about $70{ }^{\circ} \mathrm{C}$ in a drying oven. Colourless crystals of 2 appeared after several days.

The intensity data were collected on a Nonius KappaCCD diffractometer, using graphite-monochromated $\mathrm{Mo} \mathrm{K}_{\alpha}$ radiation. Data were corrected for Lorentz and polarization effects; absorption was taken into account on a 
semi-empirical basis using multiple-scans. ${ }^{[43-45]}$ The structures were solved by direct methods $\left(\mathrm{SHELXS}{ }^{[46]}\right)$ and refined by full-matrix least squares techniques against $\left|F_{o}\right|^{2}$ (SHELXL-97 ${ }^{[46]}$ ). The hydrogen atoms bound to the water molecule $\mathrm{O}(1 \mathrm{~W})$ of 1 were located by difference Fourier synthesis and refined isotropically. All other hydrogen atoms were included at calculated positions with fixed thermal parameters. All non-disordered, non-hydrogen atoms were refined anisotropically. ${ }^{[46]}$ DIAMOND was used for structure representations. ${ }^{[47]}$ Crystallographic data are compiled in Table 7. Further crystallographic data have been deposited at the Cambridge Crystallographic Data Centre under CCDC1862572 for $\mathbf{1}$, and CCDC-1862573 for 2 containing the supplementary crystallographic data excluding structure factors; this data can be obtained free of charge via www.ccdc.cam.ac.uk/conts/retrieving.html (or from the Cambridge Crystallographic Data Centre, 12, Union Road, Cambridge CB2 1EZ, UK; fax: (+44) 1223-336-033; or deposit@ccdc.cam.ac.uk).

\begin{tabular}{|c|c|c|}
\hline Refined parameters & 219 & 767 \\
\hline Goodness-of-fit on $|F|^{2}$ & 1.079 & 1.039 \\
\hline Residuals (all data) & $\begin{array}{l}R_{1}=0.0479, w \\
0.1166\end{array}$ & $\begin{array}{l}R_{1}=0.1191, w R_{2}= \\
0.2633\end{array}$ \\
\hline $\begin{array}{l}\text { Max. features in last } \\
\text { Difference Fourier synthesis }\end{array}$ & 1255 and -646 e.nm ${ }^{-3}$ & $\begin{array}{l}5869 \text { and }-2312 \\
\text { e.nm }\end{array}$ \\
\hline
\end{tabular}

Supporting Information (see footnote on the first page of this article): Crystal structure of compound 1 viewed from [101] (Figure S1). Connection between anions and cations in compound 2 (Figure S2) Crystal structure of 2 viewed on (001) (Figure S3). Newman projection of $N, N$-dimethylformamide (DMF) molecules in 2 (Figure S4). Bond lengths in 1 and 2 (Tables S1 and S2)
Table 7. Crystallographic Data

\begin{tabular}{|c|c|c|}
\hline Compound & 1 & 2 \\
\hline Empirical formula & $\mathrm{C}_{32} \mathrm{H}_{29} \mathrm{NCd}_{2} \mathrm{O}_{12}$ & $\mathrm{C}_{119} \mathrm{H}_{113} \mathrm{~N}_{15} \mathrm{Cd}_{4} \mathrm{O}_{23}$ \\
\hline Crystal system & Monoclinic & Triclinic \\
\hline Space group & C2/c (no.15) & $-($ no.2) \\
\hline Lattice constants & $\begin{array}{l}a=1821.30(6) p m \\
b=2175.08(6) p m \\
c=1269.87(4) p m \\
\beta=129.684(1)^{\circ}\end{array}$ & $\begin{array}{l}a=1224.84(4) \mathrm{pm} \\
b=1418.85(5) \mathrm{pm} \\
c=2033.49(4) \mathrm{pm} \\
\alpha=85.831(2)^{\circ} \\
\beta=88.351(2)^{\circ} \\
\gamma=68.261(1)^{\circ}\end{array}$ \\
\hline Cell volume & $3.8714(2) \mathrm{nm}^{3}$ & $3.27391(17) \mathrm{nm}^{3}$ \\
\hline Formulas in unit cell & 4 & 1 \\
\hline Formula weight & $844.36 \mathrm{~g} \mathrm{~mol}^{-1}$ & $2570.84 \mathrm{~g} \mathrm{~mol}^{-1}$ \\
\hline Density (calc.) & $1.449 \mathrm{~g} \mathrm{~cm}^{-3}$ & $1.304 \mathrm{~g} \mathrm{~cm}^{-3}$ \\
\hline Wavelength & 71.0 & $3 \mathrm{pm}$ \\
\hline Absorption coefficient & $1.153 \mathrm{~mm}^{-1}$ & $0.709 \mathrm{~mm}^{-1}$ \\
\hline $\begin{array}{l}\text { Numerical absorption } \\
\text { correction }\end{array}$ & $\begin{array}{l}\min . / \max . \\
\text { transmittance } \\
0.6841 / 0.7456\end{array}$ & $\begin{array}{l}\min . / \max . \\
\text { transmittance } \\
0.6539 / 0.7456\end{array}$ \\
\hline Temperature & & 2) $\mathrm{K}$ \\
\hline Crystal size (mm) & $0.104 \times 0.094 \times 0.084$ & $0.088 \times 0.082 \times 0.076$ \\
\hline$F(000)$ & 1680 & 1308 \\
\hline$\Theta$-range & $1.87^{\circ}-27.47^{\circ}$ & $2.09^{\circ}-27.45^{\circ}$ \\
\hline Limiting indices & $\begin{array}{l}\text { h: }-23 /+23 ; k:-28 /+28 \\
\text { l: }-16 /+15\end{array}$ & $\begin{array}{l}\text { h: }-15 / 14 ; k:-15 /+18 \\
\text { l: }-26 /+26\end{array}$ \\
\hline Reflections collected & 13612 & 20389 \\
\hline Independent reflections & $4427\left(R_{\text {int }}=0.0314\right)$ & $14138\left(R_{\mathrm{int}}=0.0341\right)$ \\
\hline Structure refinement & \multicolumn{2}{|c|}{ Full-matrix least-squares on $|\mathrm{F}|^{2}$} \\
\hline
\end{tabular}

Keywords: Methanetetra-p-benzoic acid - Cadmium • Coordination polymer - Crystal structure - Metal-Organic Framework

\section{References}

[1] L. Ma, C. Abney, W. Lin, Chem. Soc. Rev. 2009, 38, 1248-1258.

[2] M. Plabst, L.B. McCusker, T. Bein, J. Am. Chem. Soc. 2009, 131, 18112-18118

[3] A.C. Sudik, N.W. Ockwig, A.R. Millward, A.P. Cote, O.M. Yaghi, J. Am Chem. Soc. 2005, 127, 7110-7118

[4] M. O'Keeffe and O. M. Yaghi, Chem. Rev. 2012, 112, 675-702.

[5] R. Köferstein and C. Robl, Z. Anorg. Allg. Chem. 2015, 641, 1886-1891.

[6] D. Poleti and L. Karanović, Acta Cryst. 1989, C45, 1716-1718.

[7] R. Köferstein and C. Robl, Z. Anorg. Allg. Chem. 2005, 631, 1035-1037.

[8] Z.-J. Lin, J. Lü, M. Hong, R. Cao, Chem. Soc. Rev. 2014, 43, 5867-5895.

[9] O. Ermer and A. Eling, Angew. Chem. Int. Ed. 1988, 27, 829-833.

[10] O. Ermer, J. Am. Chem. Soc. 1988, 110, 3747-3754.

[11] L. Cao, P. Wang, X. Miao, Y. Dong, H. Wang, H. Duan, Y. Yu, X. Li, P. J. Stang, J. Am. Chem. Soc. 2018, 140, 7005-7011.

[12] L. Ma, A. Jin, Z. Xie, W. Lin, Angew. Chem. Int. Ed. 2009, 48, 9905-9908.

[13] J. Kim, B. Chen, T. M. Reineke, H. Li, M. Eddaoudi, D. B. Moler, M. O'Keeffe, O. M. Yaghi, J. Am. Chem. Soc. 2001, 123, 8239-8247.

[14] M. Zhang, Y.-P. Chen, H.-C. Zhou, Cryst. Eng Comm. 2013, 15, 9544-9552.

[15] R. P. Davies, R. Less, P. D. Lickiss, K. Robertson, A. J. P. White, Cryst. Growth Des. 2010, 10, 4571-4581.

[16] X. Jiang and H.-Z. Kou, RSC Adv. 2015, 15, 89052-89055.

[17] Y. E. Cheon and M. P. Suh, Chem. Eur. J. 2008, 3961-3967.

[18] M. Almáši, V. Zeleňák, M. Opanasenko, J. Čejka, Dalton Trans. 2014, 43, 3730-3738.

[19] Y. E. Cheon and M. P. Suh, Chem. Comm. 2009, 2296-2298.

[20] H. Chun, D. Kim, D. N. Dybtsev, K. Kim, Angew. Chem. Int. Ed. 2004, 43, 971-974.

[21] H. Furukawa, F. Gándara, Y.-B. Zhang, J. Jiang, W. L. Queen, M. R. Hudson, O. M. Yaghi, J. Am. Chem. Soc. 2014, 136, 4369-4381.

[22] M. Almáši, V. Zeleňák, R. Gyepes, S. Bourrelly, M. V. Opanasenko, P. L. Llewellyn, J. Čejka, Inorg. Chem. 2018, 57, 1774-1786.

[23] X. Jiang, H.-Z. Kou, Chem. Comm. 2016, 52, 2952-2955. 
[24] M. Almáši, V. Zeleňák, A. Zukal, J. Kuchár, J. Čejka, Dalton Trans. 2016, 45, 1233-1242.

[25] M. Almáši, V. Zeleňák, R. Gyepes, A. Zukal, J. Čejka, Colloids Surf. A. 2013, 437, 101-107.

[26] M. Almáši, V. Zeleňák, M. V. Opanasenko, J. Čejka, Catal. Lett. 2018, 148, 2263-2273.

[27] N. E. Brese and M. O'Keeffe, Acta Cryst. 1991, B47, 192-197.

[28] A. Bondi, J. Phys. Chem. 1964, 68, 441-451.

[29] G. Schultz and I. Hargittai, J. Phys. Chem. 1993, 97, 4966-4969.

[30] S.-Z. Hu, Z.-H. Zhou, B. E. Robertson, Z. Kristallogr. 2009, 224, 375-383.

[31] T. C. Stamatatos, E. Katsoulakou, V. Nastopoulos, C. P. Raptopoulou, E. Manessi-Zoupa, S. P. Perlepes, Z. Naturforsch. 2003, 58b, 1045-1054.

[32] Q. Shi, R. Cao, D.-F. Sun, M.-C. Hong, Y.-C. Liang, Polyhedron 2001, 20, 3287-3293.

[33] W. Clegg, J. T. Cressey, A. McCamley, B. P. Straughan, Acta Cryst. 1995, C51, 234-235.

[34] A. Tahli, Ü. Köc, R. F. M. Elshaaeawy, A. C. Kautz, C. Janiak, Crystals 2016, 6, 23.

[35] J. K. Shiba and R. Bau, Inorg. Chem. 1978, 12, 3484-3488.

[36] C. Gagnon, A. L. Beauchamp, D. Tranqui, Can. J. Chem. 1979, 57, 1372-1376.

[37] M. A. Romero, M. N. Moreno, J. Ruiz, M. P. Sanchez, F. Nieto, Inorg Chem. 1986, 25, 1498-1501.

[38] M. O. Sinnokrot, E. F. Valeev, C. D. Sherrill, J. Am. Chem. Soc. 2002, 124, 10887-10893.

[39] L. Han, H.-M. Luo, Q.-H. Meng, Y.-F. Luo, R.-H. Zeng, Acta Cryst. 2010, E66, o68-069.

[40] T. J. Zimmermann and T. J. J. Müller, Synthesis 2002, 9, 1157-1162.

[41] M. Grimm, B. Kirste, H. Kurreck, Angew. Chem. 1986, 98, 1095-10099.

[42] S. Harms, Dissertation, Univ. Jena, Germany, 2010.

[43] COLLECT, Data Collection Software; Nonius B.V., Netherlands, 1998

[44] Z. Otwinowski and W. Minor, Processing of X-Ray Diffraction Data Collected in Oscillation Mode, in Methods in Enzymology, Vol. 276, Macromolecular Crystallography, Part A, (Eds.: C.W. Carter, R.M. Sweet, Academic Press, San Diego, USA, 1997, pp. 307-326.

[45] SADABS 2.10, Bruker-AXS inc., Madison, WI, USA, 2002.

[46] G. M. Sheldrick, Acta Cryst. 2015, C71, 3-8.

[47] Diamond - Crystal and Molecular Structure Visualization, Crystal Impact H. Putz and K. Brandenburg GbR, Kreuzherrenstr. 102, 53227 Bonn, Germany. 


\title{
Syntheses and Crystal Structures of Two Cadmium Methanetetrabenzoate Featured by Open Framework and Infinite Layers
}

\author{
Sven Harms ${ }^{[a]}$, Roberto Köferstein ${ }^{[\mathrm{b}]}$, Helmar Görls ${ }^{[a]}$, and Christian Robl ${ }^{*[a]}$
}

a Institute of Inorganic and Analytical Chemistry, Friedrich-Schiller-University Jena, Humboldtstrasse 8, 07743

Jena, Germany.

Institute of Chemistry, Inorganic Chemistry, Martin Luther University Halle-Wittenberg, Kurt-Mothes-Strasse 2 , 06120 Halle, Germany.

* Corresponding author. E-mail address: crr@uni-jena.de

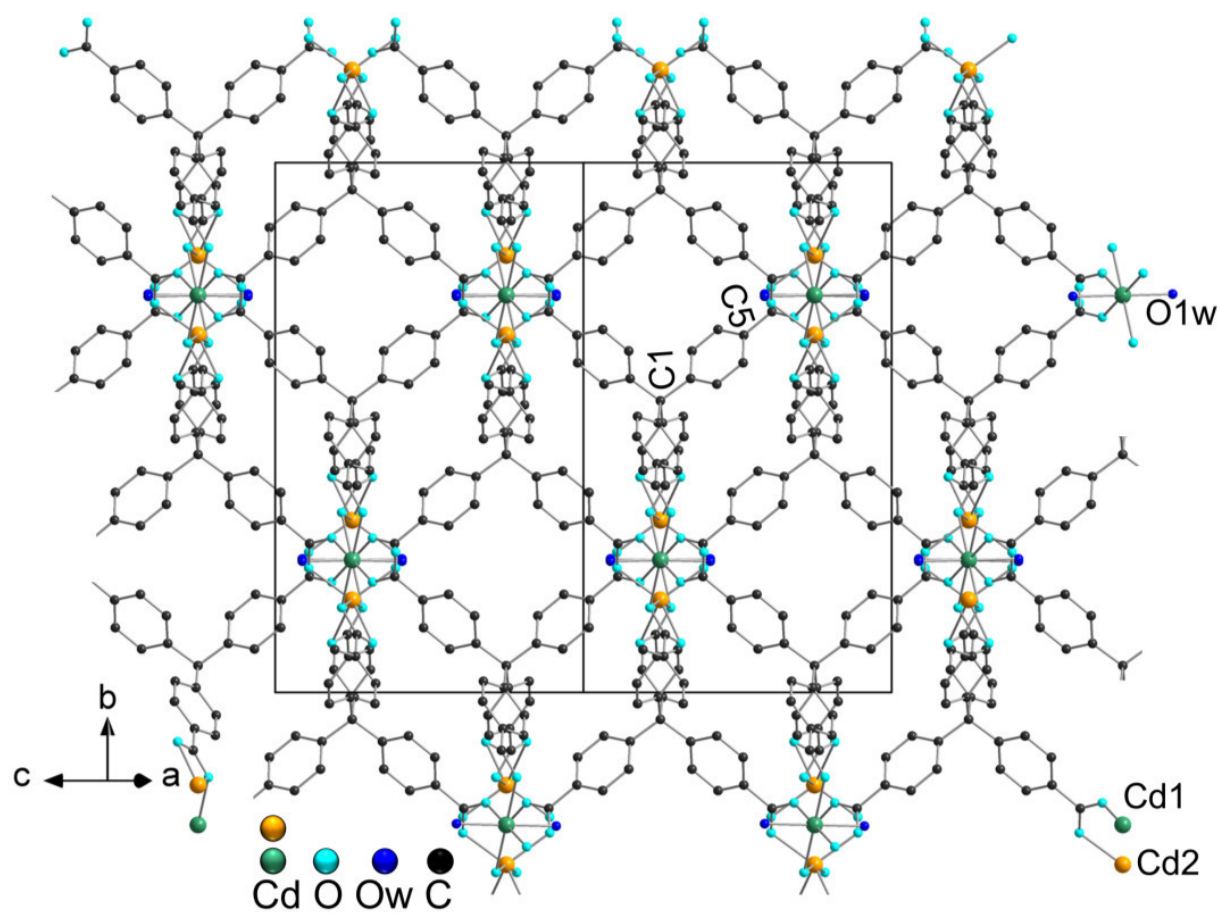

Figure S1. Connection between the $\mathrm{MTB}^{4-}$ anions and the $\mathrm{Cd}^{2+}$ cations in $\mathrm{Cd}_{2}\left[\mu_{8}-\mathrm{MTB}\right] \cdot 3 \mathrm{H}_{2} \mathrm{O} \cdot \mathrm{DMF}(1)$ viewed from [101]. Hydrogen atoms, uncoordinated water molecules $[\mathrm{O}(2 \mathrm{w})$ and $\mathrm{O}(3 \mathrm{w})]$ and $\mathrm{DMF}$ molecules are omitted for clarity. 


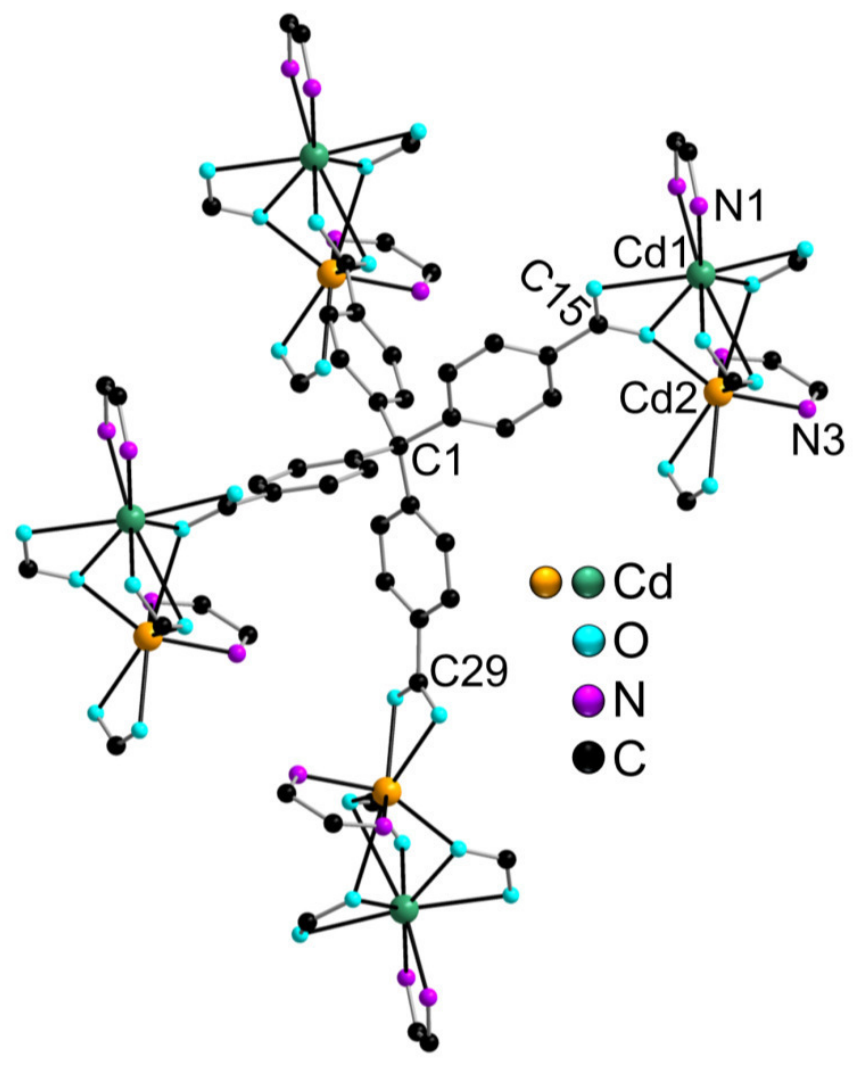

Figure S2. Connection between the $\mathrm{MTB}^{4-}$ anions and the dimeric $\mathrm{Cd}^{2+}$ polyhedra units in $\left[\mathrm{Cd}_{4}\left(2,2^{\prime}-\mathrm{bipy}_{4}\left(\mu_{7^{-}}\right.\right.\right.$ MTB) $\left.)_{2}\right] \cdot 7 D M F(2)$. Hydrogen atoms are omitted for clarity.

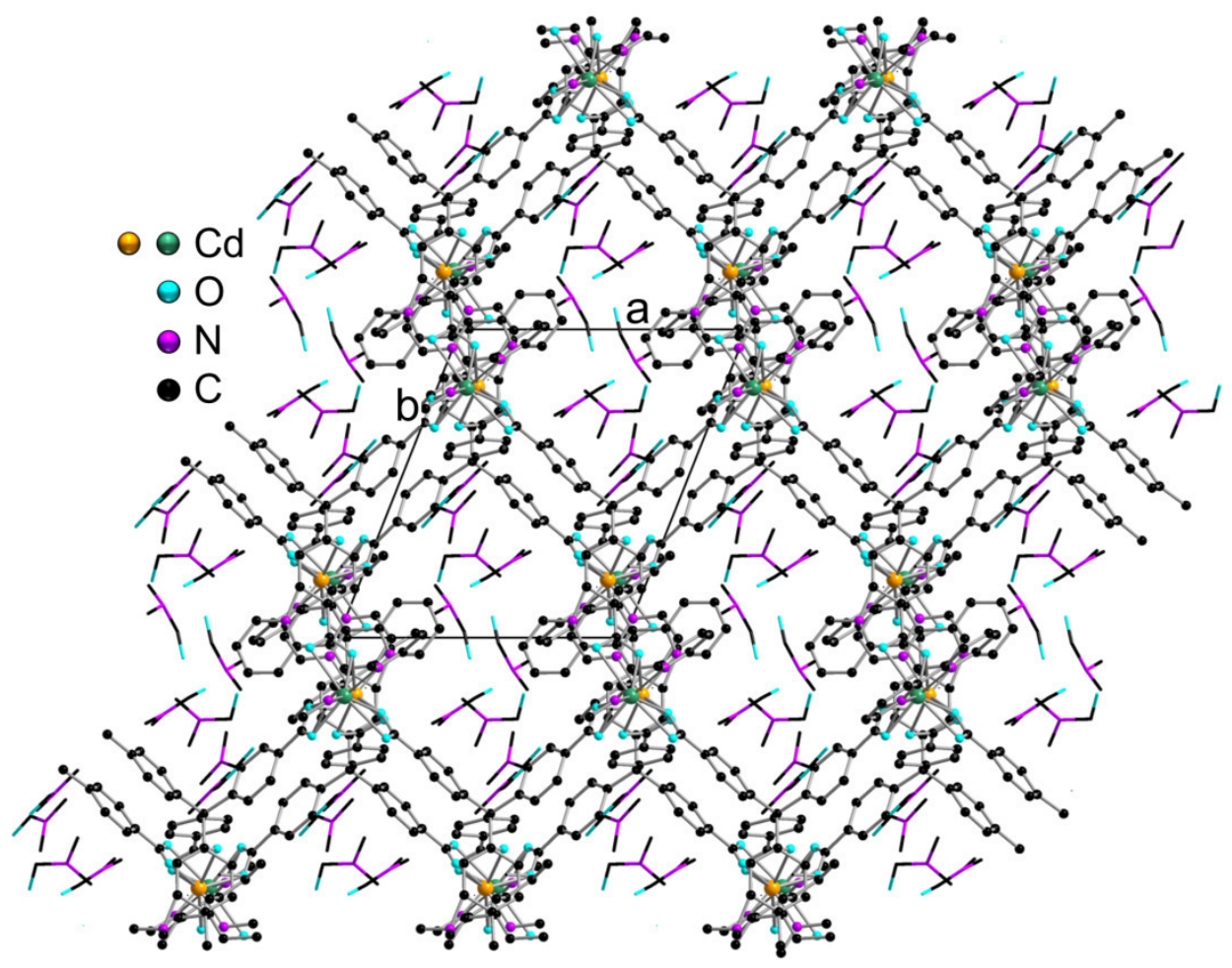

Figure S3. The crystal structure of $\left[\mathrm{Cd}_{4}\left(2,2^{\prime} \text {-bipy }\right)_{4}\left(\mu_{7}-\mathrm{MTB}\right)_{2}\right] \cdot 7 \mathrm{DMF}(2)$ view on (001). DMF molecules are drawn as sticks. Hydrogen atoms are omitted for clarity. 


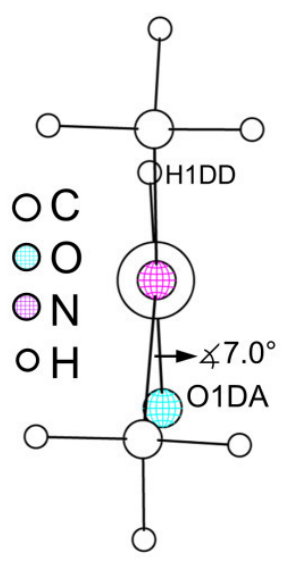

I

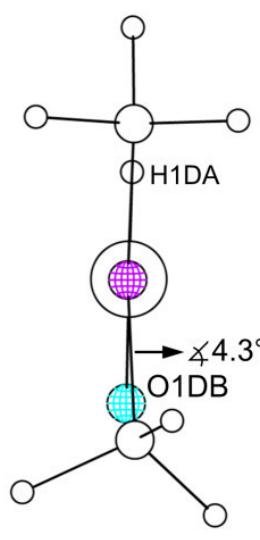

II

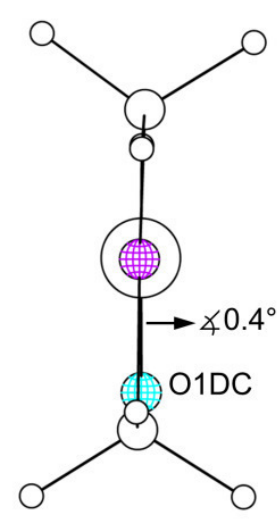

III

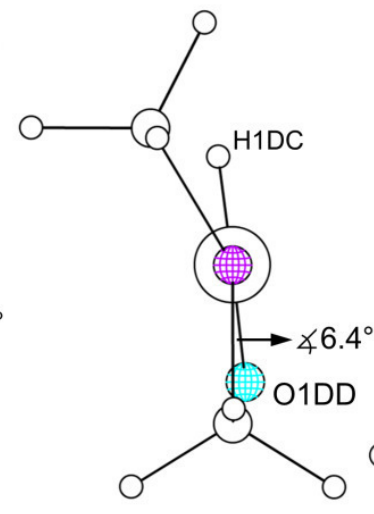

IV

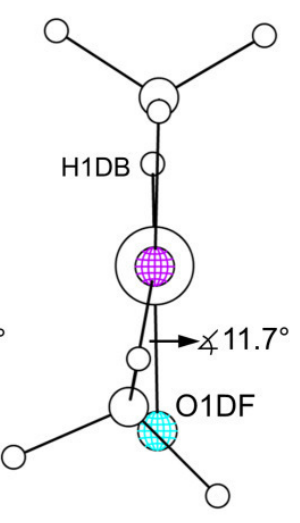

V

Figure S4. Newman projection of $N, N$-dimethylformamide (DMF) molecules along $\mathrm{N}-\mathrm{C}$ in $\left[\mathrm{Cd}_{4}\left(2,2^{\prime}-\mathrm{bipy}_{4}\left(\mu_{7}-\right.\right.\right.$ $\mathrm{MTB})_{2}$ ] 7DMF (2). The indicated values describe the smallest $\mathrm{C}-\mathrm{N}-\mathrm{C}-\mathrm{O}$ torsion angle. (e.s.d.'s: 7(2), 4(2), 0(3), $6(5), 12(4))$

Table S1. Bond lengths $(\mathrm{pm})$ of the $\mathrm{MTB}^{4-}$ anion and $\mathrm{N}, \mathrm{N}$-dimethylformamide (DMF) in $\mathrm{Cd}_{2}\left[\mu_{8}-\mathrm{MTB}\right] \cdot 3 \mathrm{H}_{2} \mathrm{O} \cdot \mathrm{DMF}(1)$

\begin{tabular}{|c|c|c|c|c|c|c|c|}
\hline \multicolumn{8}{|c|}{ Methanetetra-p-benzoate tetraanion (MTB ${ }^{4-}$ ) } \\
\hline $\mathrm{C}(8)-\mathrm{O}(1)$ & $127.6(5)$ & $\mathrm{C}(15)-\mathrm{O}(3)$ & $125.4(5)$ & $\mathrm{C}(8)-\mathrm{O}(2)$ & $124.7(5)$ & $\mathrm{C}(15)-\mathrm{O}(4)$ & $127.0(5)$ \\
\hline$C(5)-C(8)$ & $151.0(5)$ & $C(12)-C(15)$ & $149.5(5)$ & $C(1)-C(2)$ & $154.5(4)$ & $C(1)-C(9)$ & $155.3(4)$ \\
\hline $\mathrm{C}(2)-\mathrm{C}(3)$ & $139.3(5)$ & $C(2)-C(7)$ & $139.8(5)$ & $C(3)-C(4)$ & $139.0(5)$ & $C(4)-C(5)$ & $138.7(5)$ \\
\hline$C(5)-C(6)$ & $138.8(5)$ & $C(6)-C(7)$ & $138.3(5)$ & $C(9)-C(10)$ & $138.8(5)$ & $C(9)-C(14)$ & $140.6(5)$ \\
\hline$C(10)-C(11)$ & $139.4(5)$ & $C(11)-C(12)$ & $138.7(6)$ & $C(12)-C(13)$ & $138.7(5)$ & $C(13)-C(14)$ & $138.5(5)$ \\
\hline \multicolumn{8}{|c|}{$\mathrm{N}, \mathrm{N}$-dimethylformamide (DMF) } \\
\hline$O(1 A)-C(1 A)$ & $1.20(2)$ & $N(1 A)-C(2 A)$ & $1.36(2)$ & $N(1 A)-C(3 A)$ & $1.45(2)$ & $N(1 A)-C(1 A)$ & $1.43(2)$ \\
\hline
\end{tabular}

Table S2. Bond lengths (pm) of the $\mathrm{MTB}^{4-}$ anion, $2,2^{\prime}$-bipyridine, and $N, N$-dimethylformamide (DMF) in Cd $4\left(2,2^{\prime}-\right.$ bipy $_{4}\left(\mu_{7}-\mathrm{MTB}_{2}\right)^{-7} \cdot 7 \mathrm{DMF}(2)$

\begin{tabular}{|c|c|c|c|c|c|c|c|}
\hline \multicolumn{8}{|c|}{ Methanetetra-p-benzoate tetraanion $\left(\mathrm{MTB}^{4-}\right)$} \\
\hline $\mathrm{C}(8)-\mathrm{O}(1)$ & $124.9(10)$ & $\mathrm{C}(22)-\mathrm{O}(5)$ & $124.9(10)$ & $\mathrm{C}(8)-\mathrm{O}(2)$ & $128.3(10)$ & $\mathrm{C}(22)-\mathrm{O}(6)$ & $127.5(9)$ \\
\hline$C(5)-C(8)$ & $148.9(10)$ & $C(12)-C(15)$ & $149.0(10)$ & $C(19)-C(22)$ & $151.7(10)$ & $C(26)-C(29)$ & $152.4(10)$ \\
\hline$C(2)-C(7)$ & $138.3(10)$ & $C(2)-C(3)$ & $139.7(9)$ & $C(3)-C(4)$ & $138.8(10)$ & $C(4)-C(5)$ & $140.2(10)$ \\
\hline$C(5)-C(6)$ & $138.7(10)$ & $C(6)-C(7)$ & $138.7(11)$ & $C(9)-C(10)$ & $139.9(9)$ & $C(9)-C(14)$ & $140.6(10)$ \\
\hline$C(10)-C(11)$ & $137.8(10)$ & $C(11)-C(12)$ & $139.0(10)$ & $C(12)-C(13)$ & $139.0(10)$ & $C(13)-C(14)$ & $138.8(9)$ \\
\hline
\end{tabular}




\begin{tabular}{|c|c|c|c|c|c|c|c|}
\hline$C(16)-C(17)$ & $138.3(11)$ & $C(16)-C(21)$ & $139.7(10)$ & $C(17)-C(18)$ & $139.6(10)$ & $C(18)-C(19)$ & $138.7(10)$ \\
\hline$C(19)-C(20)$ & $138.5(11)$ & $C(20)-C(21)$ & $139.1(10)$ & $C(23)-C(24)$ & $138.7(11)$ & $C(23)-C(28)$ & $140.6(10)$ \\
\hline$C(24)-C(25)$ & $139.2(10)$ & $C(25)-C(26)$ & $140.0(11)$ & $C(26)-C(27)$ & $139.0(12)$ & $C(27)-C(28)$ & $138.6(10)$ \\
\hline \multicolumn{8}{|l|}{ 2,2'-bipyridine (I) } \\
\hline$N(1)-C(30)$ & $133.5(11)$ & $N(2)-C(39)$ & $131.6(11)$ & $N(1)-C(34)$ & $135.4(10)$ & $N(2)-C(35)$ & $134.4(9)$ \\
\hline$C(33)-C(34)$ & $138.3(11)$ & $C(30)-C(31)$ & $141.4(12)$ & $C(31)-C(32)$ & $135.0(13)$ & $C(32)-C(33)$ & $137.5(14)$ \\
\hline$C(34)-C(35)$ & $148.8(12)$ & $C(35)-C(36)$ & $139.8(10)$ & $C(36)-C(37)$ & $136.4(14)$ & $C(37)-C(38)$ & $139.2(15)$ \\
\hline$C(38)-C(39)$ & $138.6(13)$ & & & & & & \\
\hline \multicolumn{8}{|l|}{ 2,2'-bipyridine (II) } \\
\hline$N(3)-C(40)$ & $132.2(12)$ & $N(4)-C(49)$ & $132.4(13)$ & $N(3)-C(44)$ & $134.1(11)$ & $N(4)-C(45)$ & $135.0(11)$ \\
\hline$C(44)-C(45)$ & $149.9(13)$ & $C(40)-C(41)$ & $137.8(14)$ & $C(41)-C(42)$ & $137.6(15)$ & $C(42)-C(43)$ & $137.4(15)$ \\
\hline$C(43)-C(44)$ & $138.4(12)$ & $C(45)-C(46)$ & $137.6(13)$ & $C(46)-C(47)$ & $137.3(16)$ & $C(47)-C(48)$ & $137.6(18)$ \\
\hline$C(48)-C(49)$ & $140.3(16)$ & & & & & & \\
\hline \multicolumn{8}{|c|}{$\mathrm{N}, \mathrm{N}$-dimethylformamide (DMF) (I) } \\
\hline$O(1 D A)-C(1 D A)$ & $125.3(14)$ & $\mathrm{N}(1 \mathrm{DA})-\mathrm{C}(1 \mathrm{DA})$ & $129.6(14)$ & $\mathrm{N}(1 \mathrm{DA})-\mathrm{C}(2 \mathrm{DA})$ & $144.0(14)$ & $N(1 D A)-C(3 D A)$ & $153.0(18)$ \\
\hline \multicolumn{8}{|c|}{$N, N$-dimethylformamide (DMF) (II) } \\
\hline $\mathrm{O}(1 \mathrm{DB})-\mathrm{C}(1 \mathrm{DB})$ & $119.3(13)$ & $N(1 D B)-C(1 D B)$ & $134.6(12)$ & $N(1 D B)-C(2 D B)$ & $144.1(13)$ & $N(1 D B)-C(3 D B)$ & $144.6(14)$ \\
\hline \multicolumn{8}{|c|}{$\mathrm{N}, \mathrm{N}$-dimethylformamide (DMF) (III) } \\
\hline $\mathrm{O}(1 \mathrm{DC})-\mathrm{C}(1 \mathrm{DC})$ & $124(3)$ & $\mathrm{N}(1 \mathrm{DC})-\mathrm{C}(1 \mathrm{DC})$ & $131(2)$ & $N(1 D C)-C(2 D C)$ & $141(2)$ & $N(1 D C)-C(3 D C)$ & $144.6(19)$ \\
\hline \multicolumn{8}{|c|}{$N, N$-dimethylformamide (DMF) (IV) } \\
\hline $\mathrm{O}(1 \mathrm{DD})-\mathrm{C}(1 \mathrm{DD})$ & $122(3)$ & $\mathrm{N}(1 \mathrm{DD})-\mathrm{C}(1 \mathrm{DD})$ & $138(4)$ & $N(1 D D)-C(2 D D)$ & $139(3)$ & $N(1 D D)-C(3 D D)$ & $140(3)$ \\
\hline \multicolumn{8}{|c|}{$N, N$-dimethylformamide (DMF) (V) } \\
\hline $\mathrm{O}(1 \mathrm{DE})-\mathrm{C}(1 \mathrm{DE})$ & $136(3)$ & $N(1 D E)-C(1 D E)$ & $129(3)$ & $N(1 D E)-C(2 D E)$ & $146(3)$ & $N(1 D E)-C(3 D E)$ & $145(3)$ \\
\hline
\end{tabular}

